Proc. Estonian Acad. Sci. Geol., 2005, 54, 4, 225-259

\title{
The Pirgu Regional Stage (Upper Ordovician) in the East Baltic: lithostratigraphy, biozonation, and correlation
}

\author{
Linda Hints, Asta Oraspõld, and Jaak Nõlvak
}

Institute of Geology, Tallinn University of Technology, Estonia pst. 7, 10143 Tallinn, Estonia; Linda.Hints@gi.ee, Jaak.Nolvak@gi.ee

Received 11 April 2005, in revised form 23 September 2005

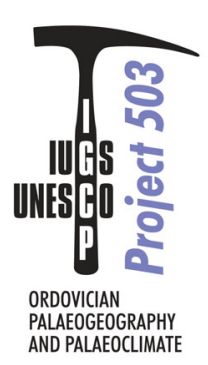

\begin{abstract}
The Upper Ordovician Pirgu Regional Stage of the East Baltic is represented by numerous formations, which characterize the lithological variability of the rocks and are used in the geological mapping of the region. Onshoreoffshore drill core profiles from northern Estonia to southern Lithuania provide data on the distribution and succession of the formations. The formations described are arranged into four groups, each comprised of units with similar and characteristic lithological composition and depositional facies. Chitinozoan biozonation and bentonite (K-bentonite) beds are used to correlate selected sections and in the facies analysis of the described formations. Special attention is paid to the age and interpretation of the Jonstorp Formation in the East Baltic and Scandinavia. Correlations of the Pirgu Stage across the East Baltic are presented, and the use of the last occurrence of the chitinozoan Acanthochitina barbata Eisenack as a marker for the lower boundary of the stage is discussed.
\end{abstract}

Key words: Upper Ordovician, Pirgu Stage, litho- and biostratigraphy, East Baltic.

\section{INTRODUCTION}

The Pirgu Stage, established in Estonia, is used as a chronostratigraphic unit in the uppermost Ordovician of the East Baltic and Poland (Männil \& Meidla 1994; Modliński \& Szymański 1997). Lately this stage has been included in the strati- 
graphic chart as a standard unit of the Ordovician in Baltoscandia corresponding to the upper part of the sixth global stage, just below the Hirnantian Stage (Nielsen 2004; Webby et al. 2004). In Sweden and Norway the same stratigraphical interval has been included in the Jerrestad Stage (Jaanusson 1982a,b; Owen et al. 1990), or the stages of the British scale are used (Smelror et al. 1997; Dahlqvist 2004).

The Upper Ordovician Pirgu Regional Stage and its subdivisions (Nyby, Lohu, and Piirsalu "zones", in ascending order) were established by Jaanusson (1944, 1956) for the upper part of the Lyckholm'sche Schicht of Schmidt $(1858,1881)$. The stratigraphy of this stage has been revised several times since the 1960s. The most complete correlation charts of the Ordovician in the East Baltic were worked out in the 1980s and 1990s (Brangulis 1978; Männil 1987; Männil \& Meidla 1994). However, later researches have made some changes in this chart, concerning also the Pirgu Stage (Kaljo et al. 1988; Meidla 1996; Nõlvak 1997; Paškevičius 1997; Stinkulis 2003; Hints et al. 2004; Nielsen 2004).

The type locality of the Pirgu Stage lies on the Atla River bank in central Estonia (15 km north of the town of Rapla, close to Pirgu Manor; Fig. 1), where the section in a thickness of about $1.5 \mathrm{~m}$ represents the late Pirgu Adila Formation (Rõõmusoks 1967b, 1983). In northern Estonia the stage has been subdivided by differences in shelly fauna into the lower and upper substages, represented by the Moe and the Adila Formation, respectively (Rõõmusoks 1960; Männil 1966, 1990; Männil \& Meidla 1994). Substage rank units of the Pirgu Stage outside northern Estonia are not clearly identified due to the lack of diagnostic criteria for tracing the boundary between these substages in different facies belts.

The aim of the paper is to summarize the published data on the Pirgu Stage and present new data with the goal of clarifying the composition, correlation, and facies succession of the stage in the East Baltic. The authors hope that the presented material serves to summarize the East Baltic data, so it can be used in studies of sequence stratigraphy and basin development before the endOrdovician glacio-eustatic sea-level changes. Short descriptions of the formations are presented and the interpretations of units by different authors analysed. The successions of the formations along the onshore-offshore profiles from northern Estonia up to southern Lithuania are illustrated by the drill core sections (Fig. 1). The chitinozoan biozonation and data on bentonite beds are employed in the correlation of the sections and the analysis of facies shifts caused by sea-level rises and falls. The lithostratigraphic units (more than 20 formations and members) of the Pirgu Stage in the East Baltic have been arranged into four groups (lithotypes; in Hints et al. 2004), each of which characterizes a distinct depositional facies, similar to those identified by Harris et al. (2004) in western Estonia and Latvia. Still, there are conceptual differences in the interpretation of formations as lithostratigraphic units and depositional sequences. 


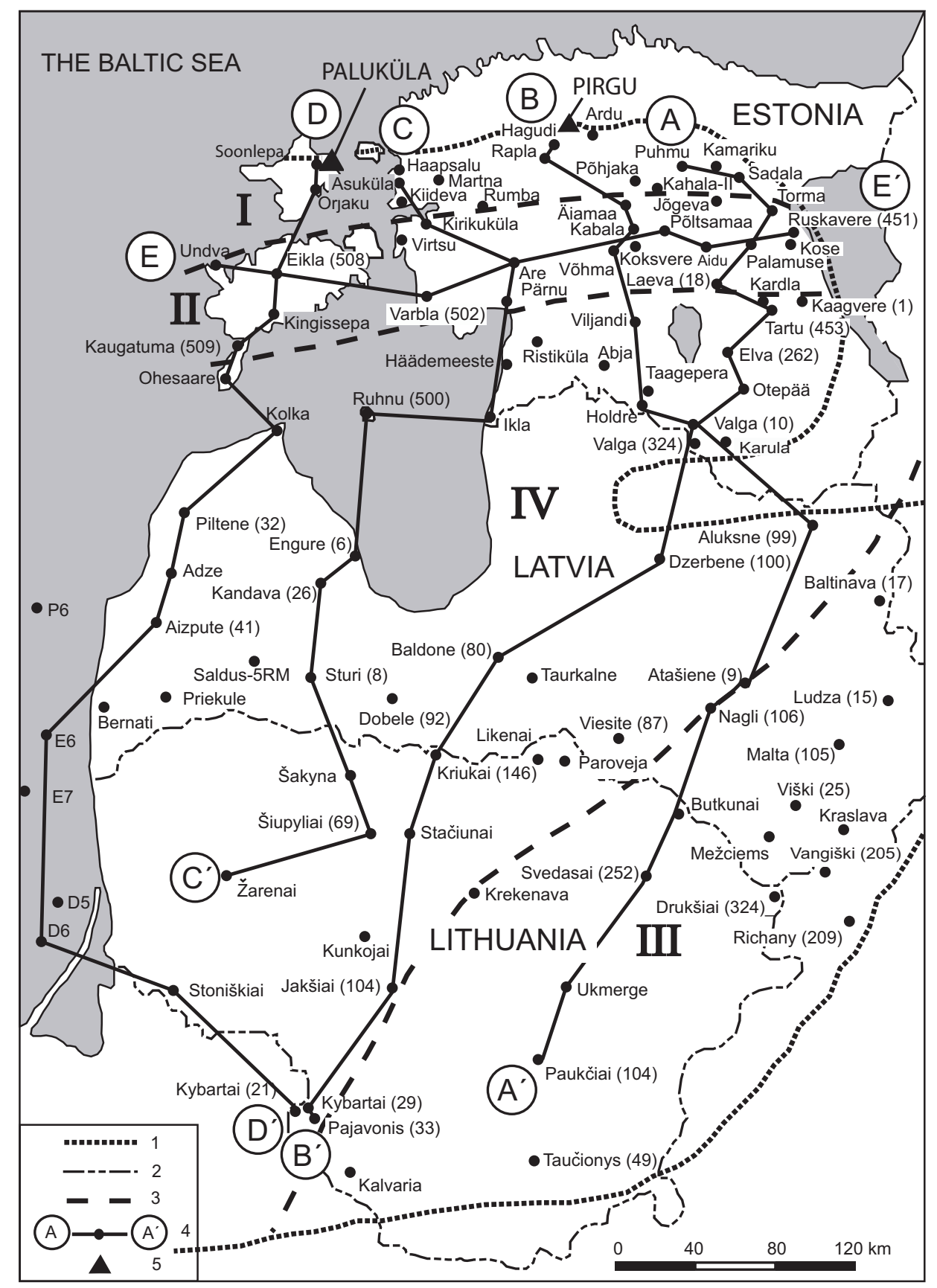

Fig. 1. Location of drill cores and outcrops mentioned in the paper or used for the characterization of lithounits. 1, boundary of the distribution area of the Pirgu Stage; 2, administrative boundaries; 3, boundary between the facies belts; 4, profiles in Figs. 5-9; 5, outcrop. Facies belts: I, North Estonian; II, transitional; III, Lithuanian; IV, Livonian Tongue. The initial numbers of the drill cores (in brackets next to the name) are not repeated in the text and figures. 


\section{GEOLOGICAL BACKGROUND}

The carbonate rocks of the Pirgu Stage accumulated during the differentiation stage of the evolution of the Baltic Basin (Põlma 1982; Hints et al. 1989; Nestor $\&$ Einasto 1997). Based on the main facies differences, the North Estonian (Estonian Shelf in Harris et al. 2004) and Lithuanian facies belts (confacies in Jaanusson 1995) and the Livonian Tongue of the Central Baltoscandian Facies Belt (Livonian Basin in Harris et al. 2004) are distinguished in the basin. Each regional stage is characterized by specific features on the background of the general facies pattern. Differences in thickness and lithology of units within the Pirgu Stage differentiate the onshore part of the shallow shelf (I in Fig. 1), and the transitional belt from deeper shelf to slope (II in Fig. 1) in the Estonian Facies Belt (Kaljo et al. 1988). The onshore part (I) consists of the Moe and Adila formations, represented in outcrops, quarries, and drill cores, whereas in the offshore part (II) the different formations are known only from drill core sections. The Estonian Facies Belt is characterized by increase in the thickness of deposits in the offshore direction and an abrupt thinning at the transition to the Livonian Tongue. A similar trend in the facies successions, but less expressed by the studied sections, characterizes the southeastern East Baltic (transition from the Lithuanian Facies Belt to the Livonian Tongue; Fig. 1). The regional Jelgava depression (see Männil 1966, fig. 2) is an elongate in a southwest-northeast direction structure, with the thickest sections of the Pirgu Stage in central Latvia in the middle part of the Livonian Tongue.

The Pirgu Stage is the thickest (up to 93 m; Ulst et al. 1982, 1984; Laškovas 2000) among the Ordovician stages in the East Baltic. The stage is missing in some westernmost sections (Ohesaare core in southwestern Estonia) or has restricted thickness (about $5 \mathrm{~m}$ in the Kaliningrad Region; Laškov \& Paškevičius 1989) due to pre-Porkuni submarine erosion or nondeposition. In the southeastern edge of the distribution area of the Pirgu Stage, the thickness of the stage decreases rapidly from $61.1 \mathrm{~m}$ in Svedasai to $35.8 \mathrm{~m}$ in Vangiški and $8.5 \mathrm{~m}$ in Richany (Fig. 1; Ropot \& Pushkin 1987) due to the pre-Silurian erosion of the Ordovician rocks.

Among the numerous lithostratigraphic units of the Pirgu Stage (Fig. 2) only the Moe and Adila formations (Rõõmusoks 1960, 1967a,b) are exposed in the outcrops and old quarries in northern Estonia, where a diverse association of shelly fauna has been collected (Rõõmusoks 1967b, 2004). High diversity of different faunal groups in the Pirgu Stage is a result of the co-occurrence of a great number of species having a long stratigraphical range (brachiopods Eoplectodonta schmidti (Lindström), Ilmarinia sinuata (Pahlen), Triplesia insularis (Eichwald), trilobites Toxochasmops eichwaldi (Schmidt), Encrinurus moe Männil, etc.) and species appearing for the first time in the Moe or Adila formations: new species among tabulate and rugose corals, brachiopods Leptaena multirugosa Rõõmusoks, 


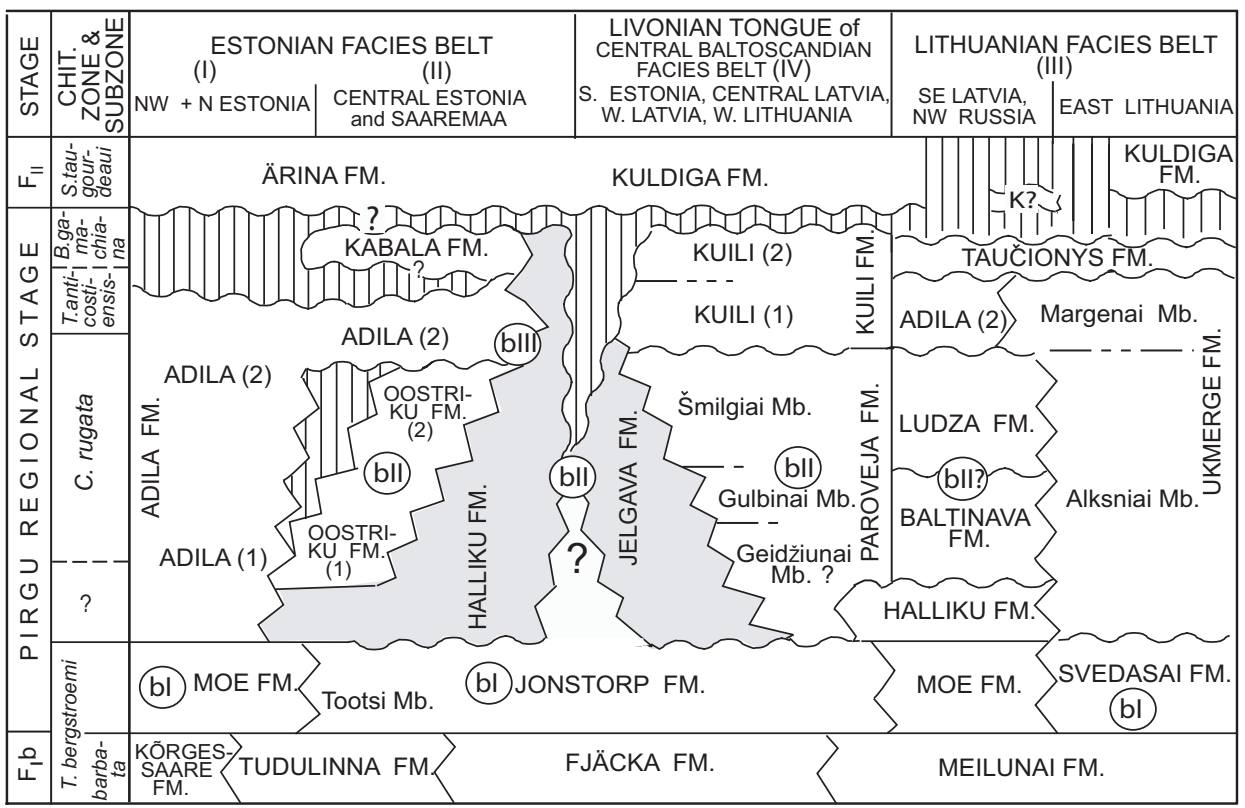

Fig. 2. Correlation of the Pirgu Regional Stage in the East Baltic. $F_{I} b$, Vormsi Stage; $F_{\text {II }}$, Porkuni Stage (only the lower part is shown); K, Kuldiga Formation; bentonite beds bI, bII, and bIII are marked on their approximate stratigraphic positions in the sections; vertical ruling denotes the stratigraphic interval of the gaps; grey shading indicates the Halliku and Jelgava formations, see also Figs. 5-8. The question mark shows the possible occurrence of early Pirgu deposits. Chit., Chitinozoan.

Geniculina pseudoalternata (Schmidt), Luhaia vardi Rõõmusoks, and Platystrophia humilis Oraspõld, trilobites Atractopyge vardiana Männil, Scotoharpes costatus (Angelin), and Pseudosphaerexochus roemeri Schmidt. According to the correlation by Nielsen (2004), the Adila Formation of the Pirgu Stage is correlated with the Porkuni age Kuldiga Formation comprising the Hirnantia Fauna in the central East Baltic. This correlation is in contradiction with our earlier data on microand macrofossils, and data on $\delta^{13} \mathrm{C}$ (Kaljo \& Hints 1997; Kaljo et al. 1999, 2001, 2004; Brenchley et al. 2003).

Ostracods, which are one of the best studied faunal groups in the drill cores, show a high taxonomic diversity in the Pirgu Stage of Estonia (about 120 species; Meidla 1996), but many of the species are long-ranged and extend through several stages. However, the ostracod associations and several species appearing in the Pirgu Stage are used in biostratigraphy or in the analysis of biofacies differences. Four ostracod associations have been identified in the Pirgu Stage: the Steusloffina cuneata-Medianella blidenensis and Uhakiella curta associations in the lowermost Pirgu Stage of northern and southern Estonia, respectively, and the Steusloffina cuneata-Olbianella fabacea and Steusloffina cuneata-Rectella romboformis associations in the upper half of the stage (Meidla 1996). 
The Pirgu Stage corresponds to four chitinozoan biozones (Nõlvak 1997, 1999, 2002). The upper part of the Tanuchitina bergstroemi Biozone (above the Acanthochitina barbata Subzone in the uppermost Vormsi Stage; Fig. 2) in the lowermost Pirgu Stage is succeeded upwards by the Conochitina rugata, Tanuchitina anticostinensis, and Belonechitina gamachiana biozones (Nõlvak 2002). Unfortunately the chitinozoans, as other organic-walled microfossils, have been destroyed in red-coloured and mottled rocks, which limits the precision of their correlation with grey-coloured rocks.

The Pirgu Stage embraces the middle part of the Amorphognathus ordovicicus conodont Biozone. The first and last appearances of the zonal conodont species fall into the Nabala and Porkuni stages, respectively (Männik 2001). A. ordovicicus is recorded from the Moe and Adila formations (Männik 1992); it has a continuous range in the Jonstorp Formation (Ruhnu cores; Männik 2003) and is identified in the upper half of the Jelgava Formation and in the Paroveja and Kuili formations (Valga core; Männik 2001).

\section{MATERIAL, METHODS, AND TERMINOLOGY}

This study is based on data from more than 100 drill core sections (Fig. 1), including the original dataset and earlier published and unpublished (descriptions of sections by A. Oraspõld and L. Põlma) data. Main attention is paid to the sections in Estonia and Latvia, as the net of the studied drill cores is less dense in the easternmost and southern parts of the East Baltic, particularly in Lithuania. Characterization of the Pirgu rocks is based on the lithological description of drill core sections, and data from thin sections and chemical analyses. The percentage of organodetrital material (skeletal debris) in the rock composition was determined from thin sections (Kirs 1967; Lepisto 1967; Põlma 1972a,b; Oraspõld 1992). The chemical analyses prepared at the Institute of Geology at Tallinn University of Technology and at the Institute of Geology of the University of Tartu were used to determine the ratios of the main constituent parts of the rocks (calcite and dolomite) and insoluble residue (mainly clay). Secondary dolomite is a common component in all studied samples, forming a few per cent up to $70-80 \%$ (in easternmost Estonia) of the rock. The terminology used to describe the size of crystals (coarse-crystalline to cryptocrystalline) in the sedimentary rocks follows that of Põldvere \& Kleesment (1998). The grain size scale for these terms differs from the scale of Friedman (1965) in more detailed calibration of grain size intervals on the decimal scale $(>0.005 \mathrm{~mm}$ - cryptocrystalline, $0.01-0.005 \mathrm{~mm}$ - microcrystalline, $0.05-0.01 \mathrm{~mm}$ - very finely crystalline, $0.1-0.05 \mathrm{~mm}$ - finely crystalline, $0.1-1.0 \mathrm{~mm}$ - medium-crystalline, and $>1.0 \mathrm{~mm}$ - coarse-crystalline).

The data available on the occurrence of bentonites in the Pirgu Stage (Männil et al. 1968; Nõlvak 1984; Oraspõld \& Põldvere 1992; Meidla 1996) are incorpo- 
rated together with recent work by Kiipli et al. (2004). The last authors have identified three correlative bentonite layers based on the differences in the content of the Na-compound of the pyroclastic sanidine. One or two, rarely three, of the bentonite beds occur in any one section, and are referred to in this paper as bI, bII, and bIII. The lowermost bentonite layer (bI) occurs in the Moe and Jonstorp, rarely in the Svedasai formations, and it is used as a correlative layer in lower Pirgu deposits. The stratigraphic position of the bentonite bII in relation to the lower boundary of the stage or bentonite bI provides an estimate of the variation of the thickness of deposits in different parts of the basin. The importance of the uppermost Pirgu bentonite (bIII) for the correlation is not clear, as it has been identified only in very few sections. Two additional bentonites are identified by Kiipli et al. (2004) in the Moe and Jonstorp formations, the correlation and stratigraphic position of which in relation to the three bentonites mentioned above are not clear. Unclear is also the correlation of the East Baltic bentonites with five bentonites in the Jerrestad mudstones and two bentonites in the Upper Jonstorp in Sweden (Jaanusson 1963).

The type sections of all units discussed in the paper are listed in the catalogue of the stratotypes (Hints et al. 1993) with reference to the original publications or are described in special publications (Brangulis et al. 1989; Sidaravičiene 1999).

A unit under the name of Oostriku is used in this study in the rank of the formation following its first interpretation (Männil \& Rõõmusoks 1984; also Meidla 1996; Nõlvak 1997 considered it a member of the Moe Formation). It forms the middle part of the Pirgu Stage and overlies the Halliku Formation. The identification of the Oostriku Formation is difficult in sections (for example, in Äiamaa) where the Halliku Formation is very thin or lithologically unclear and overlies the Moe Formation. In some older publications (Vingisaar 1977) the rocks of the Oostriku Formation are included in the Moe Formation, which has confused past correlations. The Oostriku and Adila formations are subdivided into two (lower and upper) informal units to stress the lithological differences associated with the facies shift in space and time.

The usage of the term "Jonstorp Formation" needs special explanation. Jaanusson $(1963,1982 a, b)$ established this unit first in Sweden and subdivided it into three parts, the Lower and Upper Jonstorp with the Öglunda Limestone between them. The red colour characterizes mainly the Upper Jonstorp rocks. Following Jaanusson, the term "Jonstorp" was applied in the Central East Baltic (Ulst \& Gailite 1970; Ulst 1972) to the whole sequence of the Pirgu Stage, comprising the red- and grey to yellowish-grey rocks between the Fjäcka Formation below and the Kuldiga Formation above. A similar correlation, although in contradiction to some East Baltic biostratigraphic data, was recently published by Nielsen (2004). The interpretation of the Jonstorp Formation by Männil (1966) differs from that of the authors above. He uses this term in the East Baltic only for the red-coloured rocks in the lower half of the Pirgu Stage. Later, the regional stratigraphic commission (1975) adopted this view and since then the term "Jonstorp" has 
been used in the East Baltic for the predominantly red-coloured monotonous complex of argillaceous limestones and marls in the lower part of the Pirgu Stage (Gailite 1979; Ulst et al. 1982; Männil 1987, 1990; Männil \& Meidla 1994; Hints \& Meidla 1997; Paškevičius 1997). Lapinskas (1968), however, established in the southern East Baltic the Biržai Formation to avoid the usage of the term "Jonstorp" for the predominantly red-coloured part of the Pirgu Stage between the Fjäcka and Paroveja formations (Žarenai section; Fig. 1).

In this paper the Tootsi Member (formation by Oraspõld 1992; Oraspõld \& Kala 1982; Meidla 1996; member in the Halliku Formation by Nõlvak 1997) is interpreted as a subdivision of the Jonstorp Formation. The glauconitic limestones of the Tootsi Member and red-coloured deposits of the main part of the Jonstorp Formation form the facies succession in space and time (Põlma 1982). The high taxonomic diversity of shelly fauna (Hints \& Meidla 1997) and frequency of skeletal fragments of echinoderms in many sections of the Tootsi Member differentiate this unit from the Halliku Formation.

\section{THE LOWER BOUNDARY OF THE PIRGU STAGE}

Jaanusson (1944) defined the lower boundary of the Pirgu Stage tentatively by the appearance of new fauna comprising the tabulate coral Proheliolites dubius (Schmidt) and brachiopods Eospirigerina sp., Geniculina pseudoalternata (Schmidt), and Dicoelosia sp. n., and the cephalopod Discoceras antiquissima (Eichwald). Rõõmusoks (1967a,b) described the boundary beds between the Vormsi and Pirgu stages in the west coast of Vormsi Island. However, later study showed that, at least in the northwestern coast of the island, the only rocks accessible now belong to the Vormsi Stage, containing the subzonal chitinozoan A. barbata (Nõlvak 1984, fig. 11).

The lower boundary of the Pirgu Stage in northern Estonia is traditionally understood as the boundary between the argillaceous limestones of the Kõrgessaare Formation and pure algal limestones of the Moe Formation (Rõõmusoks 1962, 1983; Oraspõld \& Kala 1982; Oraspõld 1991). The distribution of shelly fossils is known mainly from a few metres thick outcrops representing only part of the total thickness of the Moe Formation. In the latter formation several new species appear among brachiopods (Anoptambonites carinata (Holtedahlina) Rõõmusoks, Apatorthis ultima Öpik, Hebertella estonica Rõõmusoks, and Glyptorthis squamata Rõõmusoks), stromatoporoids, corals, and other groups of fossils. In the drill core sections containing sparse shelly fauna, fragments of chlorophyte algae (Palaeoporella; Kõrts et al. 1990) are abundant in the lowermost Pirgu Stage, forming local algal limestone interlayers. Many samples collected for the bed-bybed study of the Vormsi-Pirgu boundary beds in the Puhmu drill core (Fig. 1) revealed small fragments of bryozoan colonies and echinoderm ossicles. Tabulate and rugose corals and the brachiopod Eospirigerina sp. appear 2-4 m above the 
lower boundary of the Moe Formation. The latter brachiopod is represented in several samples in the limits of about $8 \mathrm{~m}$ in the lower half of the Moe Formation and is more characteristic (at least by drill core data) of the Pirgu than of the Vormsi Stage, where it appears first (in the Aulepa and Kõrgessaare quarries, Meidla et al. 1990).

In central Estonia the lower Pirgu Tootsi Member is characterized by small brachiopods of genera Sulevorthis, Skenidioides, Glyptorthis?, Laticrura, and Dicoelosia that also occur in the underlying Tudulinna Formation of the Vormsi Stage (Hints \& Meidla 1997). As in the northernmost sections, Eospirigerina sp. occurs in several successive samples in the lower part of the Tootsi Member. The large-shelled brachiopods of genera Boreadorthis, Dinorthis, Nicolella, Porambonites, Triplesia, and others, common in both the Vormsi and Pirgu stages in northern Estonia, are missing or very rare.

The Vormsi-Pirgu transition in the Livonian Tongue is marked by the disappearance of a specific fauna of small lingulates and few rhynchonelliformean brachiopods (Onniella and Chonetoidea) in the black shales (Fjäcka Formation) of the Vormsi Age. Brachiopods Rugosowerbyella, Sampo?, and Eospirigerina belong to the new association distributed in the red-coloured rocks of the lowermost Pirgu Jonstorp Formation. Data on macrofossils show only the main faunal differences between the Vormsi and Pirgu stages and do not define the exact boundary between these stages.

The Paluküla old quarry in Hiiumaa Island (Fig. 1) is the only exposure in Estonia accessible for the study of the boundary beds between the Pirgu and Vormsi stages (Meidla 1983; Oraspõld 1991; Hints et al. 1995). In the quarry wall a $3.2 \mathrm{~m}$ thick section crops out. The uppermost $1.2 \mathrm{~m}$ is represented by brownish-grey seminodular very fine to fine-crystalline limestones of the basal Moe Formation. The lower boundary of that formation coincides well with the level of the last occurrence of the subzonal chitinozoan Acanthochitina barbata Eisenack (see Hints et al. 2005). The Paluküla section, as many others in northwestern Estonia, differs from those on the mainland by the fine-grained debris of the algae Palaeoporella that forms coarse-grained algal limestone interlayers in the mainland sections (e.g. Äiamaa).

The study of chitinozoans from drill core sections, including the Orjaku core (Nõlvak 1980; see references in Nõlvak 2002; Kaljo et al. 2004, fig. 5) south of the Paluküla quarry, revealed that the boundary interval between the Vormsi and Pirgu regional stages occurs within the Tanuchitina bergstroemi chitinozoan Biozone (Nõlvak \& Grahn 1993). In the middle of this zone the Acanthochitina barbata Subzone forms a distinct biostratigraphical unit in the uppermost part of the Kõrgessaare, Tudulinna, and Fjäcka formations. The thickness of that subzone does not exceed $4.5 \mathrm{~m}$ (e.g. in the Orjaku core). The disappearance of $A$. barbata is the only relatively clear biostratigraphical event in these beds containing a rich assemblage of acid-resistant organic-walled microfossils.

The level of the last occurrence of A. barbata coincides quite well with the traditional boundary between the Pirgu and Vormsi stages in Estonia, in places 
corresponding to the boundary at a centimetre scale (e.g. in the Moe stratotype core section). This allows the use of the disappearance level of $A$. barbata as an event horizon, which precisely marks the boundary between the Pirgu and Vormsi stages. However, in some sections the age of the $2 \mathrm{~m}$ thick interval between the last A. barbata and the upper boundary of the Kõrgessaare (Orjaku and Are cores) or Tudulinna (Kamariku core) formations is not clear and additional study is needed using more closely spaced samples. The lower boundary of the Pirgu Stage is correlated by chitinozoans with the base of the Dicellograptus complanatus graptolite Zone (Nõlvak \& Grahn 1993, fig. 2; Webby et al. 2004, fig. 2.1), and it coincides roughly with the sequence boundary in Harris et al. (2004). In the southern East Baltic the last occurrences of Acanthochitina barbata are recorded in the upper part of the Meilunai Formation of the Vormsi Stage, overlain by the Svedasai Formation (Nõlvak 1988).

The Vormsi-Pirgu boundary beds are characterized, beside the biostratigraphical data mentioned above, by changes in the isotopic composition (Ainsaar et al. 2004; Kaljo et al. 2004). A positive shift of up to $2.5 \%$ is registered in $\delta^{13} \mathrm{C}$ values above the lower boundary of the stage. The boundary interval appears also as a strong reflector level on seismic submarine profiles from Hiiumaa Island up to the Gotska Sandö area in the Baltic Sea (Floden et al. 1994; Tuuling \& Floden 2001) due to a clear lithological change - argillaceous limestones or marls are overlain by pure limestones.

\section{CHITINOZOAN BIOZONES IN THE PIRGU STAGE}

The intra-regional differences in the species composition of chitinozoans in Baltoscandia are low (not exceeding 10\%; Paris et al. 2004), which provides a good basis for the biozonation by selected taxa. The Tanuchitina bergstroemi Zone corresponds to late Vormsi-early Pirgu time. In several studied sections the T. bergstroemi Zone consists of the entire Moe and Svedasai formations and the Tootsi Member of the Jonstorp Formation (Figs. 3, 4). The last appearance of the zonal species coincides often with the disappearance of other chitinozoan taxa, such as Belonechitina wesenbergensis brevis (Eisenack) and Conochitina incerta Eisenack, immediately below or very close to the upper boundary of these units.

The Conochitina rugata Zone comprises the middle part of the Pirgu Stage. It was first defined as the partial range between the first occurrences of that species and Spinachitina taugourdeaui (Eisenack) in the lowermost Porkuni Stage (Nõlvak \& Grahn 1993). Two new chitinozoan zones, Tanuchitina anticostiensis and Belonechitina gamachiana, were established later by Nõlvak $(1999,2002)$ above the C. rugata Zone in the uppermost Pirgu Stage.

Conochitina rugata (in coll. Nõlvak) occurs in the Adila, Halliku, Oostriku, Jelgava, and Ukmerge formations (Figs. 4-9). In the Estonian Facies Belt (Hagudi and Rapla cores; Fig. 6) the C. rugata Zone consists of both the lower (A1) and 


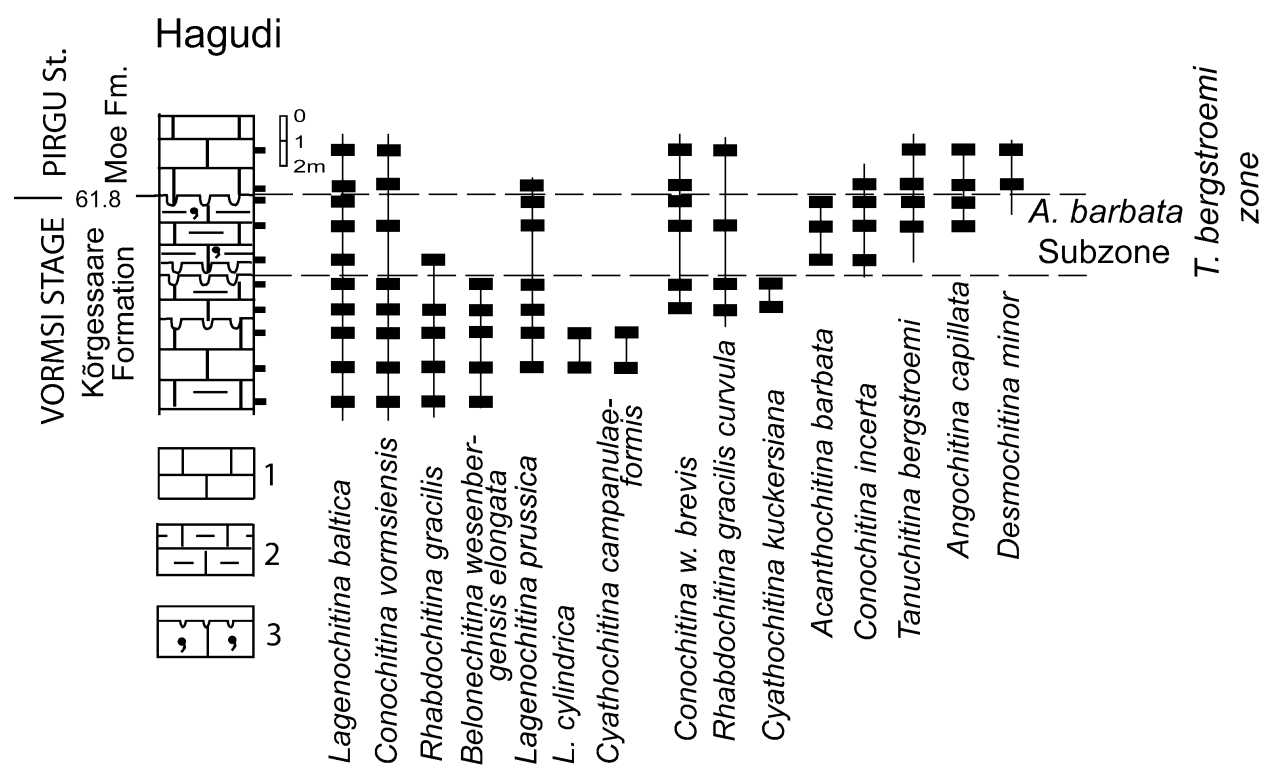

Fig. 3. Distribution of chitinozoans in the boundary beds between the Vormsi and Pirgu stages in the Hagudi core (see also Fig. 6). Legend: 1, limestone; 2, argillaceous limestone; 3, discontinuity surface (above) and glauconite grains (below).

upper (A2) parts of the Adila Formation. This species is not found in the lower part of the Oostriku Formation, which replaces the lower Adila Formation offshore. Southward the lowest occurrences of C. rugata (Eikla, Pärnu; Figs. 7, 8) are in the Halliku Formation, including the sections where this formation has restricted thickness and overlies the Moe Formation with T. bergstroemi (Äiamaa and Kirikuküla cores; Figs. 6,7). However, C. rugata occurs in certain intervals of the Halliku Formation both below and above the metabentonite bII (Figs. 5-9). In the Tartu-453 core (Fig. 5; Bauert \& Bauert 1998) it is found in the lower part of the Halliku Formation exactly above the red-coloured Jonstorp Formation. In the Livonian Tongue, C. rugata is identified in the Jelgava Formation close to the bentonite bII or in the interval with two bentonites (Figs. 5, 6). C. rugata seems to be very rare in the lower part of its vertical range and a barren interval (interzone?) occurs in some sections of central Estonia (Fig. 4). This species or some other short-ranging chitinozoan species are missing in that interval, which complicates the exact definition of the lower boundary of the rugata chitinozoan Zone.

The two topmost chitinozoan zones, the Tanuchitina anticostiensis (Nõlvak 2002, fig. 4) and Belonechitina gamachiana zones, have been identified in a few sections (Figs. 5-8) due to restricted distribution and incompleteness of the corresponding deposits in the uppermost Pirgu, especially in the Estonian Facies Belt (see Fig. 2). The former zonal species characterizes the uppermost beds of the Adila and Halliku formations (Orjaku, Hagudi, and Viljandi cores; Figs. 6, 8). 


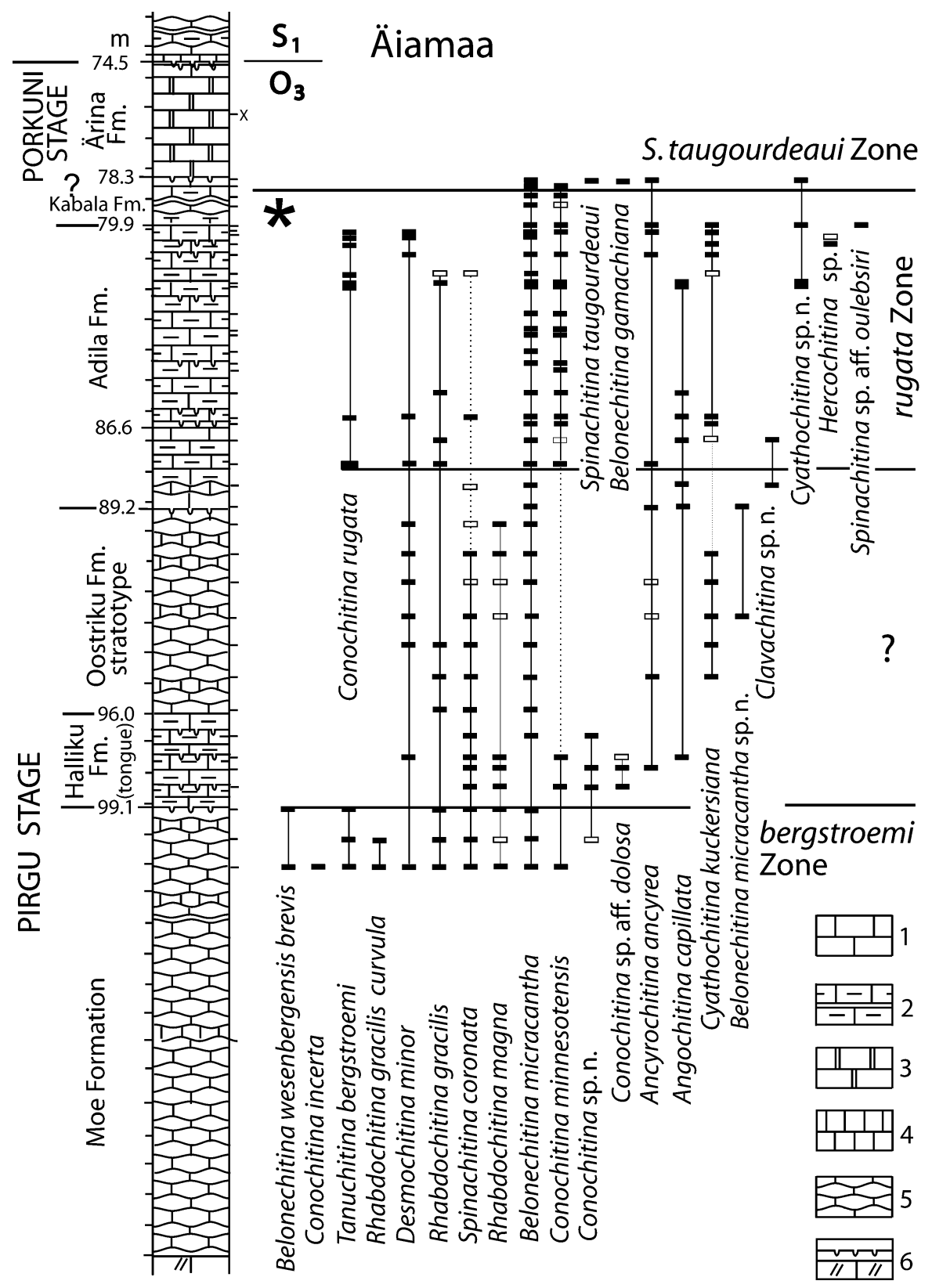

Fig. 4. The distribution of chitinozoans in the Pirgu Stage of the Äiamaa core. For the total thickness of the Moe Formation see Fig. 5. Lithological legend: 1, limestone; 2, argillaceous limestone with marl interlayer; 3 , dolomite; 4 , aphanitic limestone; 5 , nodular limestone; 6 , discontinuity surface (above), biodetritus (below). The asterisk (*) indicates the level where the late Pirgu Tanuchitina anticostiensis and Belenochitina gamachiana chitinozoan zones are not identified. The interval barren of diagnostic chitinozoans between the Tanuchitina bergstroemi and Conochitina rugata zones is shown by a question mark. "X" (on the right side of the graphic log) marks a sample without chitinozoans. 


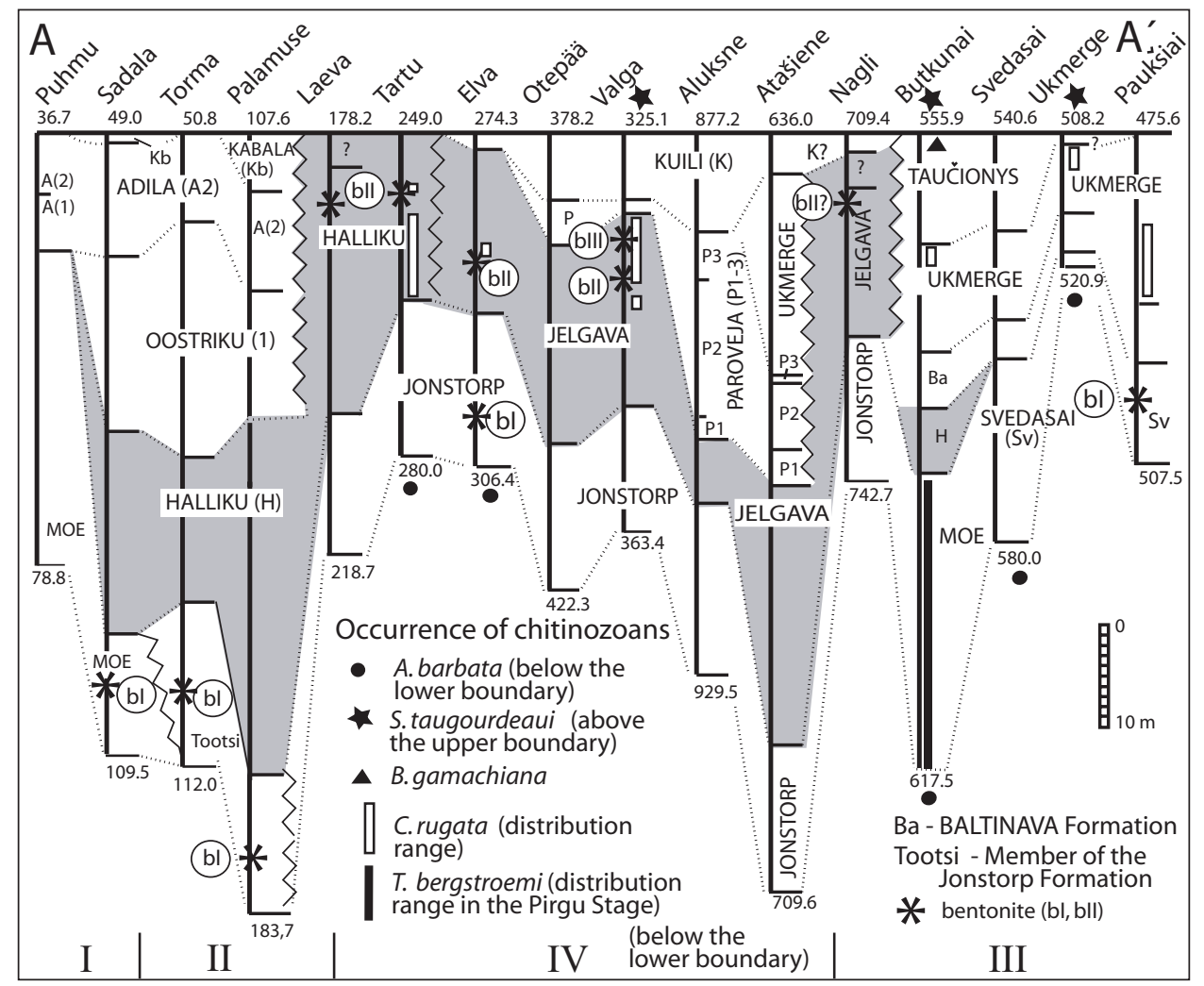

Fig. 5. Composition of the Pirgu Stage (formations) in the sections of the easternmost part of the Baltic Basin, line A-A' (see Fig. 1). The occurrence of bentonite beds (bI and bII) and zonal chitinozoans is shown. The depths of the upper and lower boundaries of the Pirgu Stage are indicated on the top and bottom of the line marking the drill core section. The argillaceous sequences of the Halliku and Jelgava formations are shown by grey shading. I-IV, facies belts in Fig. 1.

The B. gamachiana Biozone is the thickest in the Lithuanian Facies Belt, where it includes most of the Taučionys Formation characterized by the occurrence of the pentamerid brachiopod Holorhynchus giganteus Kiaer (Nõlvak et al. 1989). In the Estonian Facies Belt the zonal chitinozoan B. gamachiana Achab has been identified in the Kabala Formation (Figs. 7, 8). In the figures of the present paper the Kabala Formation is shown as part of the Pirgu Stage, but its upper boundary is not clear and needs additional study.

Webby et al. (2004) show the B. gamachiana Biozone as the lowermost zone in the Porkuni Stage of the East Baltic and in the Gamachian Stage of North America, correlated with the Hirnantian Stage of Britain characterized by the distinct Hirnantia Fauna. In the East Baltic the last fauna appears above the B. gamachiana Zone and, according to our interpretation (Nõlvak 2002; Harris et al. 2004; Kaljo et al. 2004), this chitinozoan biozone belongs to the top of the Pirgu Stage. How- 
ever, B. gamachiana occurs in some Estonian sections (Äiamaa core; Fig. 4) together with Spinachitina taugourdeaui, the first appearance of which Nõlvak (1999) proposed to be used to identify the lower boundary of the topmost Ordovician Porkuni Stage in Baltoscandia.

\section{LITHOFACIES (LITHOTYPES) OF THE PIRGU STAGE}

The formations and members of the Pirgu Stage are based on rock structure and texture, chemical composition, skeletal content, and other features (rock colour, fossil concentration) characterizing a single lithostratigraphic unit. The formations formed in more or less similar environments can be combined into four groups (lithotypes, Hints et al. 2004). The first lithotype is represented by grey to brownish-grey, micro- to cryptocrystalline, medium- $(2-10 \mathrm{~cm})$ to thick-bedded $(>10 \mathrm{~cm})$, seminodular to nodular limestones. Thin, irregular marl interlayers are $0.1-3 \mathrm{~cm}$ thick, rarely up to $10 \mathrm{~cm}$ or more. The insoluble residues of the limestones amount to $5-10 \%$, rarely up to $20 \%$. Skeletal debris forms $10-25 \%$ (in some places $50 \%$ or more) of the rock, and consists predominantly of skeletal particles of algae (Palaeoporella and Vermiporella) that comprise more than 50\% of the skeletal debris (Põlma 1972b). Shell fragments of echinoderms, ostracods, brachiopods, bryozoans, and trilobites are usually present in varying amounts. The Moe, Oostriku, Svedasai, Baltinava, Ludza, and Taučionys formations consist of relatively pure limestones of the first lithotype (Fig. 2).

The second lithotype (argillaceous limestones) comprises the late Pirgu units (Adila, Ukmerge, and Kabala formations) represented by grey to greenish-grey argillaceous micro- to very fine-crystalline limestones and marls of medium-bedded, seminodular or nodular structure. The content of insoluble residue of limestones forms 10 to $20 \%$ and of marl interlayers 25 to $50 \%$, or even $75 \%$. Skeletal debris varies from a few per cent to $30 \%$, in some interlayers to $50 \%$, and includes echinoderms, ostracods, brachiopods, trilobites, bryozoans, and algae. Fragments of algae form less than $50 \%$ of skeletal debris.

The third lithotype consists mainly of grey or red marls (insoluble residue, mostly clay $25-75 \%$ ) with micro- to very fine-crystalline argillaceous limestones (clay content 15-25\%). These rocks have wavy or nodular bedding style. Skeletal debris is distributed unevenly in different facies belts. It forms $20-45 \%$ of the rock in the Estonian Facies Belt and consists of fragments of echinoderms (most frequently), brachiopods, ostracods, trilobites, and bryozoans. In the Livonian Tongue the content of skeletal debris ranges from a few per cent up to $10 \%$ and its composition is less variable (echinoderms, ostracods, and trilobites). The Jonstorp, Halliku, Jelgava, and Kuili formations and the middle part of the Paroveja Formation consist of the third lithotype.

The fourth lithotype is represented by brownish-grey micritic (micro- to cryptocrystalline) nodular limestones with a relatively low content of insoluble 
residue $(<10 \%$ or $10-15 \%)$ and skeletal debris $(>5 \%)$, which may be absent in some intervals. These limestones have a restricted distribution in the Livonian Tongue, where they form the lower and upper parts of the Paroveja Formation. Similar limestones have been established in the middle part of the Kuili Formation in central Latvia.

\section{Pure limestones of the shallow to middle ramp (the first lithotype)}

The Moe Formation occurs in northern Estonia, eastern Latvia and Lithuania (Fig. 2). The darker, brownish-grey calcitic marl interlayers in micro- to cryptocrystalline limestones reveal the medium- $(2-10 \mathrm{~cm})$ to thick-bedded $(10-50 \mathrm{~cm})$ or seminodular structure of the rocks. The content of insoluble residue in the limestone is less than $10 \%$ and about $30 \%$ in the marl interlayers. The thickness of the formation is $24-28 \mathrm{~m}$ in western Estonia, and varies in eastern Estonia from $12 \mathrm{~m}$ (in the Sadala core) up to about $36 \mathrm{~m}$ (in the Äiamaa core; Fig. 6). The skeletal debris consists predominantly of fragments of algae (Palaeoporella and

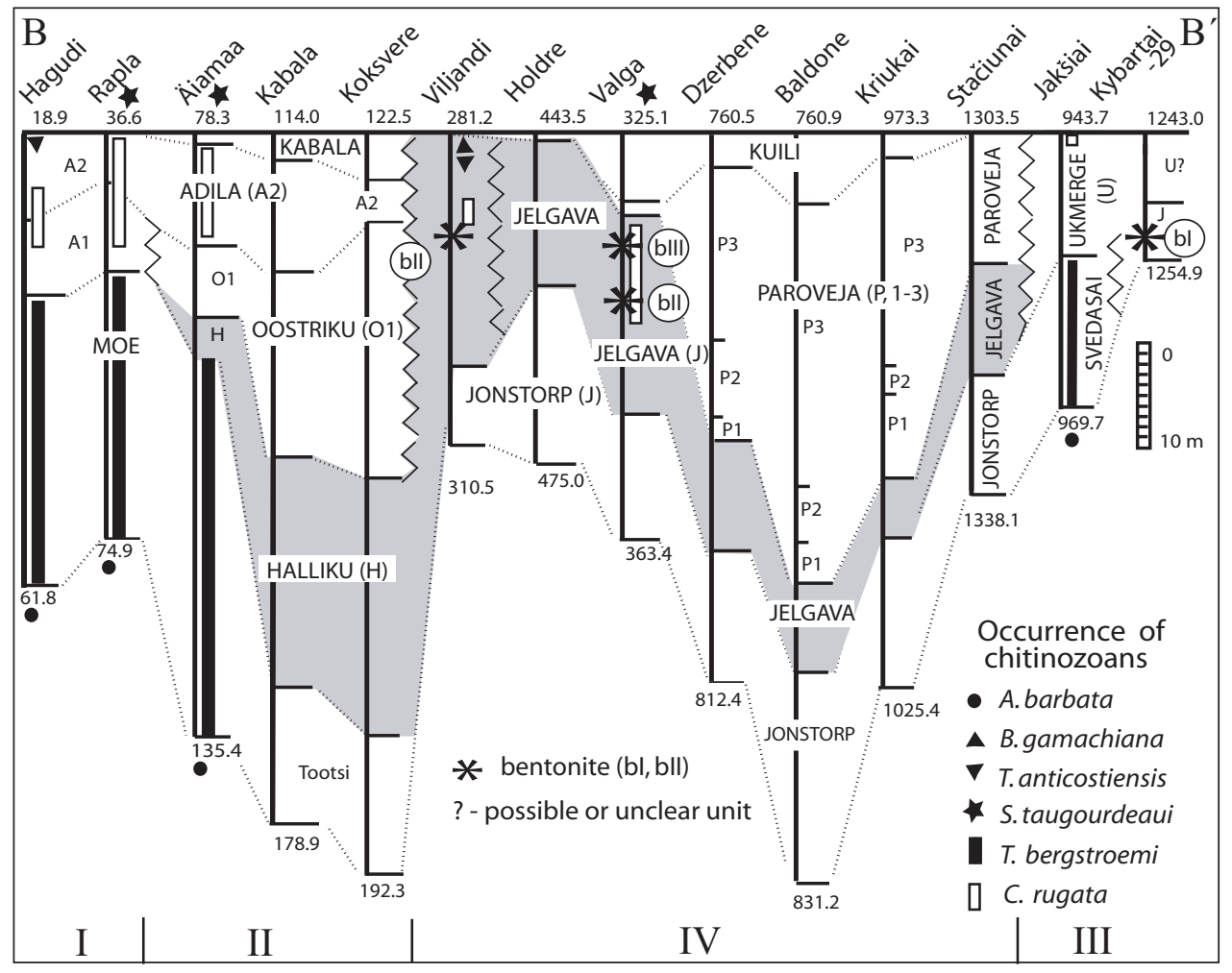

Fig. 6. Composition of the Pirgu Stage in sections along the line B-B' (see Fig. 1). 
Vermiporella), is commonly fine-grained (below $1 \mathrm{~mm}$ ), and generally forms less than $25 \%$ of the rock composition, although it is over $50 \%$ in some intervals (Põlma 1972b).

The algal debris is more common in northwestern Estonia in the lower and middle parts of the Moe Formation, where it forms algal-limestone interlayers with a thickness from a few centimetres to several metres. Several small algalcoral reefs also occur in this area (in Huitberg, Niibi, and Ruunavere; Rõõmusoks 1983).

A diverse association of shelly fossils has been collected (Rõõmusoks 1967b, 2004) from the outcrops of the Moe Formation (e.g. Moe, Niibi, Sutlepa, the old outcrops in Saxby), but in drill core sections macrofossils (brachiopods, corals, trilobites, and molluses) are quite rare and unevenly distributed. Brachiopods (of genera Eospirigerina, Dicoelosia, and Eochonetes) and rugose and tabulate corals occur in the lower half of the formation in some sections (Hints \& Meidla 1997, fig. 59), where echinoderm fragments are the most abundant skeletal fragments.

The ostracod fauna consists of more than 80 species, most of which are longranging. The fauna is marked by the appearance of Microcheilinella pirguensis Meidla, M. dagoensis Meidla, Easchmidtella orbicularis Meidla, and Pullvillites? inornatus Meidla in the upper half of the Moe Formation (Meidla 1996, figs. 8, 27, 32, 34).

The range of the zonal chitinozoan Tanuchitina bergstroemi in the Pirgu Stage includes the entire Moe Formation and the Tootsi Member of the Jonstorp Formation (in Orjaku, Hagudi, Kirikuküla, and Are; Figs. 5-7). On the basis of the distribution of chitinozoans, occurrence of a bentonite bed (bI in at least 12 sections), and facies relationship of the glauconitic and red-coloured rocks, the Moe, Svedasai, and Jonstorp formations correlate wholly or partly with the Tanuchitina bergstroemi chitinozoan Biozone.

The micro- to very finely crystalline, nodular to seminodular limestone of the Oostriku Formation was first identified in central Estonia in a thickness of $17 \mathrm{~m}$ (in the Aidu core; Fig. 9) to $24 \mathrm{~m}$ (in the Koksvere core; Fig. 6) where the lower part of the formation (O1) is represented (Figs. 5-7). In the Põltsamaa core (Fig. 9) the zonal chitinozoan C. rugata and bentonite bII (Kiipli et al. 2004) occur in the topmost part of that unit. The "Vermiporella" beds by Nõlvak (1984) found in several sections in Saaremaa Island (at 297.6-306.5 $\mathrm{m}$ in the Kingissepa core, at $348.0-354.3 \mathrm{~m}$ in the Kaugatuma core; Fig. 8) are treated here as the upper half of the Oostriku Formation (O2). The different ages of the lower and upper parts of the Oostriku Formation in Saaremaa and on the mainland were revealed by the position of the bentonite bII. It occurs in different sections either on the top of the lower half or below the upper half of the formation (Fig. 9). The youngest beds of the Oostriku Formation, contemporaneous with those in Saaremaa, are presumably of very restricted distribution on the mainland (in Varbla; Fig. 9). 


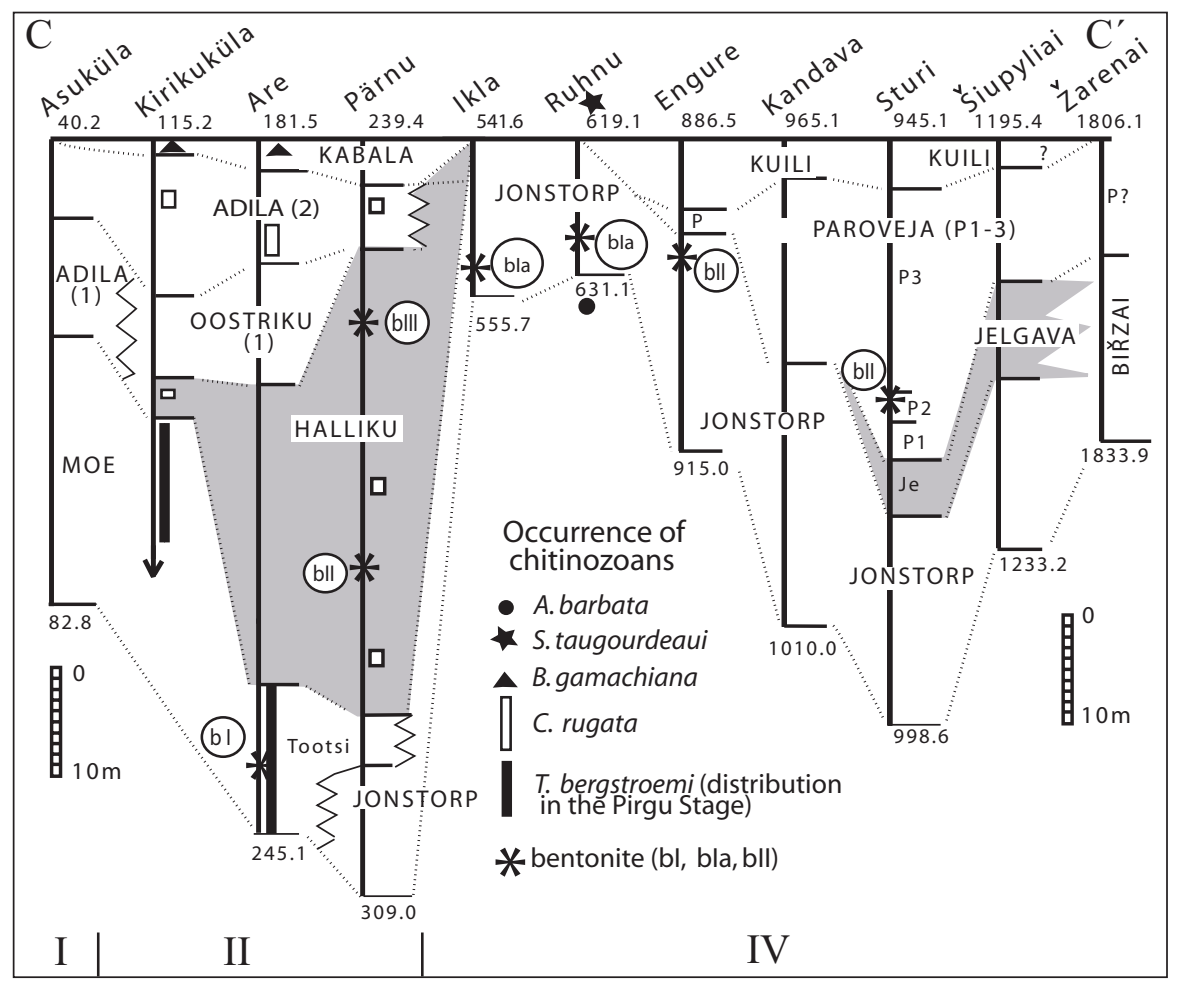

Fig. 7. Composition of the Pirgu Stage in sections along the line $\mathrm{C}-\mathrm{C}^{\prime}$ (see Fig. 1).

The Oostriku Formation displays very clear differentiation into the limestone and argillaceous interlayers $(2-10 \mathrm{~cm}$ thick) with sharp contacts. The content of insoluble residue in the limestones increases to the east and south, and the nodular structure becomes seminodular or wavy (Oraspõld \& Põldvere 1992; Oraspõld 1992). The amount of skeletal debris (fragments of algae, echinoderms, and ostracods) increases upwards from $7-10 \%$ to $50 \%$ in the Koksvere core (Kirs 1967), and to $35-40 \%$ in the Torma core (Oraspõld 1992). The Vermiporella-rich interlayers occur in the Oostriku Formation, but in some sections (Torma core; Oraspõld 1992) debris of Palaeoporella is found. The majority of the ostracod species (about 40) identified in the Oostriku Formation have a wide stratigraphical range. An exception is a rare species Fallaticella schaeferi Schallreuter, which appears in the upper half of the Oostriku (Adila by Meidla 1996, fig. 24) Formation (O2) and is presumably of late Pirgu age.

In southeastern Latvia most of the 57-92 m thick Pirgu Stage is represented by rocks of the first lithotype (Moe, Svedasai, Baltinava, Ludza, and Taučionys formations; Ulst et al. 1982; Laškov et al. 1984; Brangulis et al. 1989; Laškovas et al. 1993; Laškovas 2000; Paškevičius 1994, 1997; Sidaravičiene 1999; Fig. 2). The Moe and Svedasai formations in the lower half of the Pirgu Stage both contain 
skeletal debris of the chlorophyte algae Palaeoporella, which in the Jakšiai core (Fig. 6) forms about $20 \%$ of the rock (unpublished data by L. Põlma) in the middle part of the nodular limestones.

The Svedasai Formation is characterized mainly by ostracods of a wide stratigraphical range. Similarly to the Moe Formation in Estonia, the lower and upper parts of the Svedasai Formation include somewhat different ostracod associations. Ahlintella? marginata (Sidaravičiene), Cystomatochilina umbonata (Krause), and Kiesowia dissecta (Krause) (= K. mammilosa; Sidaravičiene 1992, 1996) are restricted to the lower half of the Svedasai Formation and species of Tetradella (T. separata Sidaravičiene, T. plicatula (Krause), and T. triloculata Schallreuter) appear in the upper half of the unit.

Data on chitinozoans, including the occurrences of the zonal Tanuchitina bergstroemi Laufeld together with Ancyrochitina ancyrea (Eisenack) and other associated species (Lagenochitina baltica Eisenack, Belonechitina wesenbergensis brevis (Eisenack), and Conochitina incerta Eisenack) in East Lithuania (Jakšiai and Butkunai sections; Fig. 6) support the correlation of most of the Svedasai Formation with the Moe Formation. The Svedasai Formation contains a bentonite bed (in the Svedasai-241, Paukčiai-192, and Jakšiai-104 cores; Laškovas 2000), which probably corresponds to the lowermost bentonite (bI) in the Pirgu Stage in Estonia. The thickness of the T. bergstroemi Zone is 14.7 and $21.2 \mathrm{~m}$ in the Jakšiai and Butkunai sections, respectively, which corresponds to the total thickness of the Svedasai and Moe formations (Fig. 5). In sections in the Drukšiai area (Fig. 1), most of the Svedasai Formation is lithologically similar (increased content of terrigeneous material) to the Latvian sections, where the Halliku and/or Baltinava formations overlie the Moe Formation. It is possible that the topmost Svedasai Formation is younger than the T. bergstroemi Zone in the Drukšiai area.

The Baltinava Formation, a well-defined interval in southeastern Latvian sections, comprises brownish-grey or grey limestone with seminodular to nodular structure and biodetrital or micritic (aphanitic) interlayers. The thickness of the formation varies from 6 to $11 \mathrm{~m}$ (Ulst et al. 1982). The boundary with the underlying Halliku Formation is transitional. A thin bentonite is present in the upper part of the formation in the Baltinava core (Ulst et al. 1982), probably corresponding to the bentonite bII in Estonia.

The nodular limestones of the Baltinava Formation are overlain by grey, bedded to nodular, biodetrital limestones with greenish-grey marl interlayers of the Ludza Formation representing the middle part of the Pirgu Stage in the easternmost study area (Ulst 1972; Ulst et al. 1982). The thickness of the latter formation is up to $23 \mathrm{~m}$. The skeletal debris consists mainly of fragments of algae Vermiporella.

The upper Pirgu Taučionys Formation, represented by micro- or cryptocrystalline nodular limestones, is the best studied unit in the southern and southeastern East Baltic (Paškevičius 1968, 1994; Ulst et al. 1982; Nõlvak et al. 1989; Brenchley et al. 1997; Nõlvak 1999; Laškovas 2000). The Taučionys Formation is known also as the Holorhynchus-beds containing a specific association of fossils and corresponding to the Belonechitina gamachiana chitinozoan Biozone of the 
uppermost Pirgu Stage. The thickness of the formation is about $10 \mathrm{~m}$ in southeastern Lithuania and more than $16 \mathrm{~m}$ in southeastern Latvia. In Estonia this zonal chitinozoan species occurs in the Kabala Formation and rare specimens and fragments of Holorhynchus are found in several sections on Hiiumaa Island (Hints 1993).

\section{Argillaceous limestones of the middle ramp (the second lithotype)}

The Adila Formation is limited to northern Estonia, where it varies in thickness from 10 to $18 \mathrm{~m}$, and easternmost Latvia, where it is 9 to $24 \mathrm{~m}$ thick. The lower boundary of the formation is diachronous. In Estonia the lower part of the Adila Formation (A1) is represented by grey to greenish-grey medium- to strongly argillaceous, micro- to very finely crystalline limestones, with a flat to seminodular bedding and discontinuity surfaces in the upper half of the unit. The upper part of the formation (A2) consists of grey to brownish-grey microcrystalline weakly argillaceous limestones with discontinuity surfaces. The nodular limestones of the Adila Formation are overlain by the reef-limestone in eastern Latvia (Ulst et al. 1982).

The argillaceous interlayers in the Adila Formation are highly bioturbated. The content of skeletal debris (fragments of echinoderms, brachiopods, trilobites, and ostracods) is commonly less than $20-25 \%$ and reaches the highest value (up to 50\%) in the layers with abundant fragments of the Vermiporella-type algae (Lepisto 1967; Põlma 1972b).

Sparse macrofossils (rugose and tabulate corals, a few brachiopods and trilobites) have been identified in the drill core sections of the Adila Formation (Ulst et al. 1982; Hints \& Meidla 1997).

The ostracod fauna of about 70 species (Meidla 1996) shows no significant differences from the Moe Formation and belongs to the Steusloffina cuneataOlbinella fabacea ostracod association distributed in the upper Moe and Adila formations. At that, in western Estonia $S$. cuneata is frequent in the Moe Formation and O. fabacea in the Adila Formation (Orjaku and Haapsalu cores in Meidla 1996, figs. 26, 27). Both species are unevenly distributed in eastern Estonia. New species (Pseudorayella kaufmanni Schallreuter and Bulbosclerites unicoris (Neckaja)) appearing in the Adila Formation enrich this ostracod association.

The chitinozoan zonal species Conochitina rugata appears close to the lower boundary of the Adila Formation (Rapla core; Fig. 6) and ranges to the top of the formation (Hagudi, Rapla, Orjaku, Undva, and Are cores; Figs. 6, 8, 9). In sections from the islands of Hiiumaa (Orjaku core) and Saaremaa (Eikla, Kaugatuma, and Kingissepa cores), this species occurs only in the uppermost carbonate part of the Adila Formation (A2, Fig. 8) but appears already in the underlying Halliku Formation.

The name Kabala was first used in geological mapping by E. Kala (Kala et al. 1967) for the rocks bounded by discontinuity surfaces between the Porkuni or 


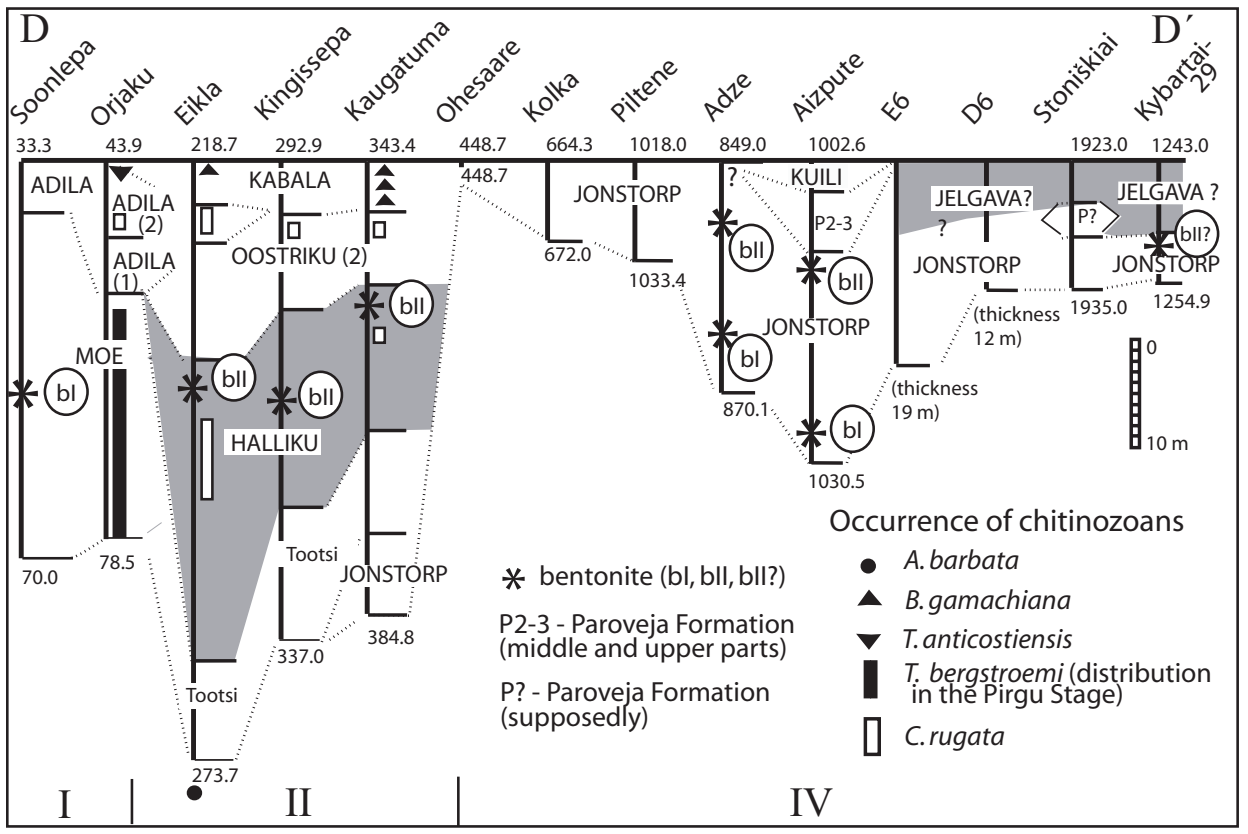

Fig. 8. Composition and correlation of the formations of the Pirgu Stage in sections along the line D-D' (see Fig. 1).

Juuru Stage above and the Adila Formation below. The Kabala Formation is 0.5 to $6.5 \mathrm{~m}$ thick (Figs. 4-9; Meidla 1996, fig. 28) and is distributed in central Estonia as far east as the Laeva area (Laeva-1 core). Intercalations of relatively thick $(3-10 \mathrm{~cm})$ layers of dark grey calcitic or argillaceous marl and light grey limestone differentiate the Kabala Formation from the underlying Adila Formation. The bedding is wavy to seminodular or nodular. Marls with limestone nodules are common in the westernmost sections. The distribution of skeletal debris is uneven, varying from a few per cent to 25-30\% (Kirs 1967; Oraspõld \& Põldvere 1992). The most common skeletal constituents are fragments of echinoderms, ostracods, algae Vermiporella, bryozoans, and brachiopods.

The Kabala Formation comprises the Belonechitina gamachiana chitinozoan Biozone at the top of the Pirgu Stage. The co-occurrence of this species with Spinachitina taugourdeaui, the characteristic species of the lowermost Porkuni Stage, in the upper part of the Kabala Formation in some sections has complicated the interpretations of the age of that formation. It has been interpreted as a member of the Adila Formation in the Pirgu Stage, or as a formation in the Pirgu-Porkuni boundary interval that is partially in the Porkuni Stage (Nõlvak 1984, 1986; Männil 1987; Nõlvak \& Grahn 1993; Meidla 1996; Kaljo et al. 1988, 2004; Harris et al. 2004). In the figures presented in this paper the Kabala Formation is shown in the composition of the Pirgu Stage. 
The "Äiamaa Formation" is mentioned in some publications (Männil \& Rõõmusoks 1984; Männil 1990) above the Adila and below the Ärina Formation. The type interval of this formation (78.3-81.7 $\mathrm{m}$ in the Äiamaa core) corresponds, according to recent stratigraphical use, to the Kabala Formation and to the uppermost Adila Formation (Fig. 6), therefore the term "Äiamaa Formation" is not used in this paper.

The Ukmerge Formation (Laškov et al. 1984; Sidaravičiene 1999) forms an 8-20 m argillaceous interval between the Svedasai and Taučionys formations, which consists of rocks of the first lithotype in the southeastern East Baltic. In southeastern Latvia the formation comprises grey argillaceous limestones with a rich association of shelly fossils (brachiopods, bryozoans, and rugose corals). In the Lithuanian sections the micro- to fine-crystalline nodular biodetrital limestones in the lower half of the formation (Alksniai Member; Fig. 2) are overlain by dolomitic marls and burrowed limestones with numerous discontinuity surfaces (Margènai Member) (Laškovas et al. 1993; Sidaravičiene 1999). The occurrence of burrows and discontinuity surfaces indicates similar environments in the southeastern East Baltic and Estonia, in the areas of the formation of the upper part of the Adila Formation. Several brachiopods characteristic of the Pirgu Stage in Estonia (Luhaia vardi Rõõmusoks, Bekkeromena semipartita (Roem.), and Eospirigerina aff. sulevi (Jaanusson)) have been identified in the Ukmerge Formation (Sidaravičiene 1999).

\section{Marls of the deep ramp (the third lithotype)}

The Jonstorp Formation (sensu stricto) consists mainly of red-coloured argillaceous limestones or calcitic marls with a maximum thickness of $25 \mathrm{~m}$ (Ulst et al. 1982; Kaljo et al. 1988) in western Latvia (Engure, Kandava, and Sturi cores; Fig. 7), where the lowermost 1-2 $\mathrm{m}$ interval consists of greenish-grey argillaceous limestones (Ulst 1992). In the Västergötland sections of Sweden (Jaanusson 1963), the $3 \mathrm{~m}$ thick Lower Jonstorp greyish-green argillaceous limestone is, at least in colour, similar to the lowermost Pirgu rocks in the East Baltic, but palaeontological data for the correlation of these beds are insufficient. All studied samples are barren of acid-resistant microfossils.

In western Latvia the red argillaceous limestones of the lowermost part of the Jonstorp Formation are replaced upwards by marls or calcitic marls (e.g. in the Priekule, Aizpute, Piltene, Engure, Kolka, and Sturi cores). In southern Estonia the insoluble residue content is about $15 \%$ in the lowermost carbonate part of the Jonstorp Formation, and it increases upward up to $26 \%$. In the eastern periphery of the Jonstorp Formation (Nagli and Atašiene cores; Fig. 5) mainly argillaceous limestones occur. The most clay-rich deposits of the formation are found in southwestern Estonia (Ristiküla and Häädemeeste; Fig. 1). The upper boundary of the Jonstorp Formation is transitional and may be diachronous (Nõlvak 2001). Microlithological studies show that the content of fine-grained (below $1 \mathrm{~mm}$ ) skeletal 
debris, mostly of echinoderms, ostracods, trilobites, and brachiopods, is relatively low, ranging from few per cent to $25 \%$.

The Jonstorp Formation includes local mud mounds in the Kaugatuma, Võhma, and Jõgeva sections (Perens 1995). These mounds (61 $\mathrm{m}$ in the Võhma core) are surrounded by deposits with a high content (up to 33\%) of skeletal debris (Pärnu, Põltsamaa, and Viljandi cores; Figs. 6, 7).

The red rocks grade in space and time into grey limestones with glauconite grains, sometimes with reddish spots of the Tootsi Member. It forms the lowermost Pirgu Stage (e.g. Ruskavere, Palamuse, Aidu, Koksvere, Kingissepa, and Eikla cores), and is the lateral equivalent of the typical red-coloured Jonstorp strata (Kaugatuma and Pärnu cores; Figs. 5-9). Its thickness is 5-16 m in central Estonia, and up to $20 \mathrm{~m}$ in eastern Estonia (Ruskavere core; Fig. 9). The Tootsi Member consists of grey or light grey, slightly greenish, variably argillaceous, micro- to very finely crystalline limestones, with intervals of calcitic marls in

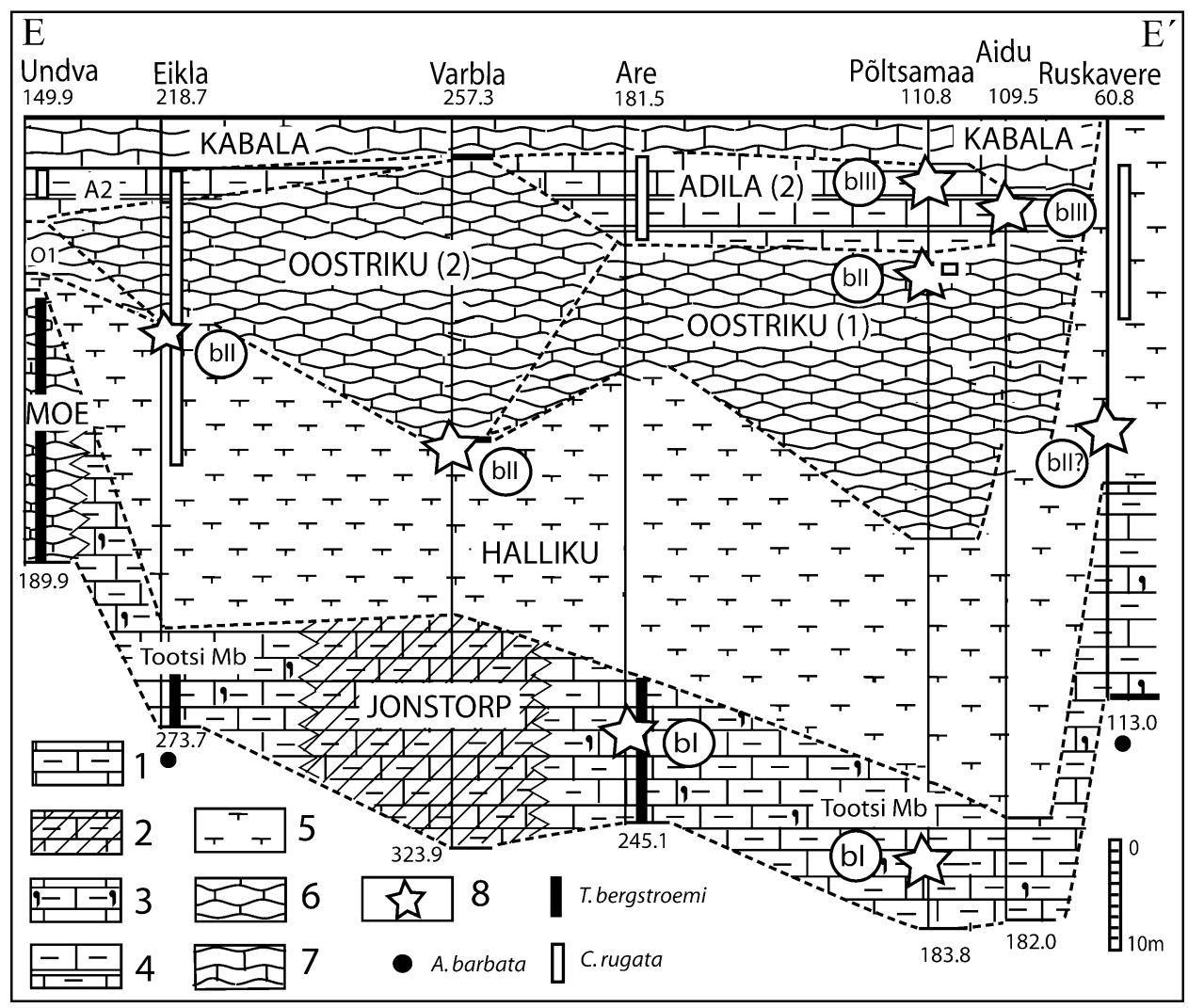

Fig. 9. Correlation of formations of the Pirgu Stage in central Estonia along the line E-E' (transitional belt, III in Fig. 1) and the distribution of zonal chitinozoans. Lithological legend, simplified: 1, argillaceous limestone; 2 , the same but red-coloured; 3 , the same with glauconite grains; 4 , the same with clayey interlayers; 5 , marlstone; 6 , micritic (aphanitic) limestone; 7 , limestone; 8 , bentonite bed. 
some sections. Glauconite grains make up less than 3\% of the rock (Põlma 1982), and violet or reddish spots are observed. The bedding of limestones is wavy, seminodular or nodular. Some discontinuities and a bentonite bed (bI) occur in the middle of the Tootsi Member (Torma, Palamuse, and Are cores; Fig. 9). This bentonite layer is supposedly of the same age as the bentonite in the red-coloured part of the formation and in the Moe Formation (Figs. 5, 7, 9). Skeletal debris comprises 10-20\%, seldom over 30\%, of the rock content (Kirs 1967; Oraspõld 1992).

Macrofossils of the Jonstorp Formation are represented by rare trilobites (of genera Tretaspis and Panderina) and brachiopods (Sowerbyella (Rugosowerbyella) rossettana (Henningsmoen), Sampo sp., Christiania sp., and Eospirigerina sp.). Unlike the other groups of fossils, conodonts show high diversity in the Jonstorp Formation (20 species, Männik 2001). The high frequency of the zonal conodont Amorphognathus ordovicicus, which first appears in the Nabala Stage, is characteristic of the whole Jonstorp Formation in some sections (Ruhnu and Mehikoorma; Männik 2003).

Several new ostracod species (Laevanotella nonguleata Meidla, Daleiella rotundata Meidla, Rectella explanata Meidla, and Gryphiswaldensis plavinensis (Gailite)) appear in both the red-coloured and glauconitic rocks of the Jonstorp Formation (Meidla 1996). Their distribution is restricted mainly with the Livonian Tongue. Among the short-lived ostracod species Hemiaechminoides excentricus Schallreuter is common in the Tootsi Member and Moe Formation (see Meidla 1996). The Tootsi Member represents a unit which comprises chitinozoans common with the Moe Formation: the zonal species Tanuchitina bergstroemi, together with Belonechitina micracantha (Eisenack), B. wesenbergensis brevis, Conochitina incerta, Lagenochitina baltica, and some others. The bentonite bI ties these two units with the red-coloured part of the Jonstorp Formation that is barren of microfossils.

The occurrence of short-ranging conodont species Icriodella sp. n. L. in the uppermost part of the Jonstorp Formation (Ruhnu) and in the Jelgava Formation (Valga-10) suggests that these units are partly contemporaneous (Männik 2001, 2003).

The Halliku Formation forms most of the Pirgu Stage in central and southernmost Estonia (Figs. 4, 6, 8). Its lower boundary is lithologically sharp only in sections where it overlies the Moe Formation. The thickness of the formation is less than $10 \mathrm{~m}$ along the margins of its distribution area (Undva, $1.5 \mathrm{~m}$; Virtsu, $6.9 \mathrm{~m}$; Kirikuküla, $3.9 \mathrm{~m}$; Äiamaa, $3.1 \mathrm{~m}$ ), over $30 \mathrm{~m}$ in eastern Estonia (Oraspõld 1975; Oraspõld \& Põldvere 1992), and up to $41.6 \mathrm{~m}$ in southwestern Estonia (Pärnu; Fig. 7). The formation consists of grey and, in the lower part, violet or red-spotted calcitic marl and medium- to strongly argillaceous micro- to very finely crystalline limestones that grade laterally to the north into argillaceous limestones. Lithologically the lowermost Halliku Formation is similar to the Jonstorp Formation, differing mainly in rock colour. 
In the Ruskavere section of easternmost Estonia the content of insoluble residue varies from 11 to $45 \%$ in the Halliku Formation. The bedding is seminodular, nodular or wavy. The content of skeletal debris (mainly of echinoderms) varies from few per cent to 20-25\%, being generally higher in some western Estonian sections (Kingissepa and Pärnu). In the Koksvere section, where the Halliku Formation is $24 \mathrm{~m}$ thick, the content of skeletal debris decreases upwards from $30-45$ to $7-15 \%$ (Kirs 1967).

The zonal chitinozoan species Conochitina rugata occurs in the Eikla, Kaugatuma, Pärnu, and Kirikuküla cores (Nõlvak 1984; Figs. 7, 8) together with Ancyrochitina ancyrea, Spinachitina coronata (Eisenack), Rhabdochitina gracilis Eisenack, and Conochitina minnesotensis (Stauffer). The topmost $2 \mathrm{~m}$ of the Halliku Formation in the Kardla section belongs to the Tanuchitina anticostiensis Biozone, and is overlain by beds $(1 \mathrm{~m})$ with the zonal chitinozoan Belonechitina gamachiana Achab. The former zonal species is found in the uppermost beds of the Adila Formation in northwestern Estonia (in the Orjaku core) and in the uppermost beds of the Halliku Formation in central Estonia (in the Viljandi core), indicating the post-rugata age of these Pirgu beds.

The ostracod fauna of the Halliku Formation is rather diverse (about 80 species; Meidla 1996) and belongs to the Steusloffina cuneata-Rectella romboformis ostracod association. The diversity of conodonts (15 species; Männik 1992) in that formation is also notable in comparison with other formations of the Pirgu Stage. Macrofossils are known in few core sections. In some sections (Kose and Ruskavere) the calcitic marls of the Halliku Formation contain small rugose corals, rare tabulate corals and brachiopods (Kullervo sp., Eochonetes sp., and Wysogorskiella cf. litviensis Hints).

Bed-by-bed correlation of closely spaced sections, trends in lithological changes, the occurrence of bentonites, and the distribution of the zonal species C. rugata show that the lowermost Halliku Formation corresponds to the lower, most argillaceous part of the Adila Formation. The middle part of the Halliku Formation is correlated with the Oostriku Formation and the topmost part can be correlated with the uppermost Adila Formation (A2) (Fig. 2).

The Halliku Formation contains at least one bentonite (bII) identified in more than 10 cores (Figs. 5-9), which can be used in the correlation of sections. This bed is not recorded in the northern Estonian sections, presumably due to numerous gaps within the middle and upper parts of the Oostriku and Adila formations, or due to later or post-Pirgu erosion of the corresponding beds in some areas. Another bentonite (bIII) in the upper part of the Halliku Formation (Pärnu core; Fig. 7) is probably contemporaneous with the bentonite in the uppermost Adila (Põltsamaa core; Fig. 9; see also Kiipli et al. 2004) and Jelgava (Valga-10; Fig. 5) formations. Nevertheless, the identification of the bentonite bIII in different sections requires additional data.

The Jelgava Formation, established in the central East Baltic, consists of greenish-grey, with red spots in the lower part, calcitic marl of variable thickness: from 12 to $14 \mathrm{~m}$ in Latvia and Lithuania (Ulst et al. 1982; Paškevičius 1997) and 
up to 15-19 m in southeastern Estonia (Valga, Otepää, and Elva cores; Figs. 5, 6), overlying the Jonstorp Formation and underlying the Paroveja or Kuili Formation. The Jelgava Formation is lithologically similar to the upper part of the Jonstorp Formation, but differs from it by the occurrence of argillaceous limestone interlayers of variable thickness. The skeletal debris, amounting to less than $10 \%$, consists primarily of echinoderms in association with ostracods, trilobites, brachiopods, and bryozoans. Macrofauna is poorly known in that formation and only a few trilobites and graptolites have been identified (Ulst et al. 1982).

The Jelgava Formation comprises the zonal chitinozoan Conochitina rugata (Nõlvak 2001). The continuous range of that species in the Valga-10 section includes two bentonites (bII, bIII; Kiipli et al. 2004).

The Kuili Formation in the top of the Pirgu Stage is represented by clayrich or calcitic marls and argillaceous limestones in a thickness of 2-6 m, rarely $10 \mathrm{~m}$ (7-8 $\mathrm{m}$ in central Latvia and $1.2-7.2 \mathrm{~m}$ in southeastern Estonia). The lower boundary is lithologically very sharp and locally marked by a discontinuity surface.

The red colour or red spots are a characteristic feature of the Kuili Formation. In central Latvia the middle part of the formation consists of grey cryptocrystalline limestones which are 0.2 to $2 \mathrm{~m}$ (Viesite and Baldone cores), but locally up to $5 \mathrm{~m}$ thick (Taurkalne; Fig. 1). In southeastern Estonia the formation is very finely crystalline and the red colour is weakly developed or replaced by mottled or grey-coloured rocks. In Lithuania the Kuili Formation consists of calcitic marls and argillaceous limestones (Šakyna and Šiupyliai cores), in which red colour is primarily developed in the upper part of the unit (Paškevičius 1997; unpublished data by L. Põlma). The content of biodetrital material as well as of shelly fossils is very low, but the bioturbation is common in the rocks of the Kuili Formation (Ulst et al. 1982; Brangulis et al. 1989; Meidla 1996, 2001).

The middle part of the Paroveja Formation (Gulbinai Member; Lapinskas 1976; Sidaravičiene 1999) is lithologically assigned to the third lithotype. In central East Baltic it consists of $7.7 \mathrm{~m}$ of greenish-grey or reddish marls with lenses of microcrystalline clayey limestones (Ulst et al. 1982; Sidaravičiene 1999). The unit forms an argillaceous part within micritic (aphanitic) limestones of the Geidžiunai Member below and the Šmilgiai Member above.

The units of the third lithotype belong to the offshore facies of the third to fifth sequences in the sequence stratigraphic model by Harris et al. (2004).

\section{Pure limestones of the deep ramp (the fourth lithotype)}

The Paroveja Formation occurs in the central East Baltic with its westernmost distribution margin reaching the Engure (Fig. 7) and Bernati cores. The formation overlies the Jelgava Formation or, in some sections (Sturi-8, Kandava-26, and Engure), the Jonstorp Formation (Männil et. al. 1968; Kaljo et al. 1988). A discontinuity surface marks the lower boundary in some cores (Taurupe-58, Dzerbene-100, and Madona-93; Ulst et al. 1982). The thickness of the formation 
varies from 20 to $30 \mathrm{~m}$, with a maximum of $38.5 \mathrm{~m}$ in central Latvia (Olaine-D-I core; Ulst \& Gailite 1976) and decreasing laterally towards its distribution limits (in southeastern Estonia 1.4-4.1 m; in westernmost Latvia $2.2 \mathrm{~m}$ in Engure, $4.1 \mathrm{~m}$ in Aizpute). The youngest part of the formation has presumably the widest spatial distribution. Sparse fossils have been identified in the Paroveja Formation: dalmanellids and "Plectatrypa" among brachiopods (Lapinskas 1968), illaenid trilobites, some conodonts (probably Amorphognathus ordovicicus by Peep Männik), and graptoloids (Laškov \& Paškevičius 1991). The lowermost part of the $1.4 \mathrm{~m}$ thick Paroveja Formation of the Valga core contains the zonal chitinozoan C. rugata and conodont A. ordovicicus (Männik 2001; Nõlvak 2001).

The Paroveja Formation is subdivided into three members (Figs. 5-8; Geidžiunai, Gulbinai, and Šmilgiai; Lapinskas 1976), whereas the middle Gulbinai unit is included in the third lithotype (see above). The lower and upper units are brownishgrey micritic (micro- to cryptocrystalline) nodular limestones with a dark grey pyritic pattern. In many sections the formation consists of microcrystalline limestones of the same kind without any subdivisions.

In southwestern Lithuania and Kaliningrad district the Fjäcka shales are overlain by nodular limestones with argillaceous interbeds (Stoniškiai and Vladimirov cores), whose exact age is not known. Southwards they are replaced by marls with a limestone interbed, which are probably contemporaneous with the lower part of the Prabuty marls and shales included in the Pirgu Stage in Poland (Modliński \& Szymański 1997).

\section{DISCUSSION AND CONCLUSIONS}

The data on the Pirgu Stage from about 100 drill core sections in the East Baltic presented in this paper enable us to correlate formations and illustrate the dynamics of facies changes along onshore-offshore transects. The stage corresponds to four chitinozoan biozones and consists of different carbonate rocks between the underlying Acanthochitina barbata Subzone (Vormsi Stage) and the overlying Spinachitina taugourdeaui Biozone (Porkuni Stage). The successions of described formations and lithotypes follow in general the depositional sequences described by Harris et al. (2004). The pre-Pirgu sea-level rise was accompanied by the spreading of organic-rich black shale to the easternmost central East Baltic and a wide distribution of $A$. barbata in different environments. The last occurrence of this zonal species coincides closely with the traditional boundary between the Vormsi and Pirgu stages in the East Baltic. The disappearance level of A. barbata can be used provisionally as a diagnostic feature of a contemporaneous horizon, which is very close to or coincident with the boundary between the Vormsi and Pirgu stages. A more precise definition of this boundary will require additional biostratigraphic study.

The arrangement of the described 14 formations of the Pirgu Stage in the East Baltic into four groups (lithotypes) enables better estimation of the shifts, changes, 
and symmetry of facies distribution in the basin. The lithological variation, a great number of lithostratigraphical units and uneven palaeontological data have complicated the correlation and compilation of models of basin development during the middle Ashgillian Pirgu time. This has caused the elaboration of different correlation charts for that time and different understanding of the lithostratigraphical units.

The units of the first (Moe, Oostriku, Svedasai, Baltinava, Ludza, and Taučionys formations) and second (Adila, Ukmerge, and Kabala formations) lithotypes have formed in the shallow to middle ramp environments of the Estonian and Lithuanian facies belts. Their spatial location in the basin shifted according to the sea-level rises and falls. The shallow-water conditions, with varying inflow of siliciclastic material and water activity (fine- to coarse-grained skeletal debris), characterized the early Pirgu (Tanuchitina bergstroemi Biozone) environments in the Estonian and Lithuanian facies belts. Changes in the faunal composition, the amount of the algal debris, content of the siliciclastic component, and in the carbon isotope composition (Kaljo et al. 2004) are probably related to the progradational facies shifts that occur within the two depositional sequences comprising the Moe Formation (Harris et al. 2004). In the upper Pirgu Stage, the facially similar limestones of the Oostriku Formation migrated basinward under shallowing-upward conditions (Conochitina rugata Biozone). The late Pirgu Taučionys Formation (first lithotype), associated with the appearance of the Holorhynchus fauna, was deposited during a transgressive episode (sequence 6 in Harris et al. 2004) across extensive areas of the southeastern East Baltic. In the Estonian Facies Belt the contemporaneous deposits belong to the Kabala Formation (B. gamachiana Biozone) with a restricted distribution.

On the background of the sea-level fall towards the end of Pirgu time, the transgressive episodes at the beginning of the deposition of the Adila and Kabala formations of the second lithotype mark the base of sequences 5 and 6 in the shallow shelf (Harris et al. 2004) of the Estonian Facies Belt. In the Lithuanian Facies Belt the analogues of the Adila Formation belong to the Ukmerge Formation.

Grey and red argillaceous limestones and marls (third lithotype) of the Jonstorp, Halliku, Jelgava, and Kuili formations, together with the middle part of the Paroveja Formation, accumulated in the offshore parts of the Estonian and Lithuanian facies belts and in the Livonian Tongue of the Central Baltoscandian Facies Belt. The total stratigraphical extent of these units corresponds to the entire Pirgu Stage. The formation of rocks of separate units started at the beginning of the transgressive episodes of the fourth (Jonstorp), fifth (Halliku or Jelgava), and sixth (Kuili) depositional sequences of Harris et al. (2004). The increased content of siliciclastic material in the middle Paroveja Formation (Gulbinai Member) in the deeper part of the basin (Livonian Tongue) indicates sea-level change in the limits of sequence 5 mentioned above. In the Estonian Facies Belt this sea-level drop is marked by the discontinuity surfaces in the middle part of the Oostriku and Adila formations. 
The Paroveja Formation represents a unique unit (fourth lithotype) in the Pirgu Stage consisting mainly of carbonate mud (an exception is the middle part). It forms a rock body spatially elongate in the southwest-northeast direction, reaching a thickness of over $38 \mathrm{~m}$ (Ulst et al. 1982) and thinning out laterally. The accumulation of these muds was presumably caused by rapid deposition and sinking of the sea bottom in the Jelgava Depression (middle of the Livonian Tongue). The rarity of fauna (Laškov \& Paškevičius 1991) and low content of skeletal debris indicate environmental conditions unsuitable for benthic organisms. This is similar to the red-coloured and spotted deposits of the Jelgava and Jonstorp, and Kuili formations bounding the Paroveja limestones below and above, respectively. These units comprise relatively sparse shelly fauna and the organicwalled microfossils are not preserved in red-coloured rocks. However, the zonal chitinozoan C. rugata is found in the lowermost part of the Paroveja Formation (Nõlvak 2001).

Some new ideas regarding the correlation of the Pirgu Stage have emerged from the distribution of bentonite beds and conodonts. The bentonites enable tracing some trends and changes in the deposition of the rocks of the Pirgu Stage during different time intervals. The lower part of the Pirgu Stage, up to the bentonite bI, includes the lower parts of the Moe, Jonstorp, and Svedasai formations. The thickest deposits of that interval formed in the easternmost transitional belt, where the lower Moe Formation or the Tootsi Member of the Jonstorp Formation reaches a thickness of $19.8 \mathrm{~m}$ (Oostriku core, SW of Kahala-II, Fig. 1). Locally in this area the thickness of the contemporaneous deposits decreases up to one-third $(6.5 \mathrm{~m}$ in the Torma and $6.7 \mathrm{~m}$ in the Põltsamaa core). The bentonite bI occurs within the early Pirgu T. bergstroemi chitinozoan Zone established in the Moe and Svedasai formations and in the Tootsi Member of the Jonstorp Formation.

The following period is characterized by a notably greater thickness $(54.1 \mathrm{~m}$ of the $73 \mathrm{~m}$ thick Pirgu Stage in the Põltsamaa core; Kiipli et al. 2004) of deposits between the bentonites bI and bII in the easternmost part of the transitional belt. This interval comprises the upper part of the Tootsi Member, Halliku Formation, and the lowermost Oostriku Formation. The stratigraphical position of the bentonite bII in relation to the bentonite bI and the boundaries of formations in different sections indicate diachronous boundaries of units and thickness variations during this time interval. Thus the Halliku Formation in the easternmost part of the transitional belt (Põltsamaa core) should be older than most of the same formation in the western part of that belt (Pärnu core).

In southwestern Estonia (Ruhnu and Ikla cores) and northwestern Latvia (Adze and Aizpute cores) the Pirgu Stage of limited thickness (7 to $20 \mathrm{~m}$ ) consists only of the Jonstorp Formation, in part due to erosion of the uppermost Pirgu beds prior to the deposition of the overlying Porkuni strata. The bentonites, one or two in each section, have not been studied chemically (Kiipli et al. 2004), still it can be supposed that they may correspond to the bentonite beds bI and bII in other sections. The correlation of the bentonite bII is supported by conodont data. The short-ranged Icriodella sp. $\mathrm{n}$. L occurs $2 \mathrm{~m}$ below the upper boundary of the 
Jonstorp Formation in the Ruhnu core and also in the middle Jelgava Formation in the Valga core (close to bentonite; Männik 2001, 2003; Nõlvak 2001; Kiipli et al. 2004). The lithostratigraphic and biostratigraphic data suggest that the red-coloured rocks (traditionally assigned to the Jonstorp Formation) accumulated in southwestern Estonia and northwestern Latvia for a longer time than in the central part of the Livonian Tongue, where similar rocks form only the lower part of the Pirgu Stage. Currently no data support the correlation of the uppermost part of the Jonstorp Formation with the Kuili Formation as proposed by Männil et al. (1968).

Grey-coloured limestones of uncertain age, ranging in thickness from $0.2 \mathrm{~m}$ (Ruhnu core; Nõlvak 2003) to $3.8 \mathrm{~m}$ (Ikla; Männil et al. 1968), occur above the Jonstorp Formation in some of the above-mentioned sections. In the Ruhnu section they are overlain by beds with S. taugourdeaui of the Porkuni Stage. In the Ikla core these beds contain some echinoderms ("Heliocrinites" sp. and "Eucystis" sp.; Männil et al. 1968), which indicates some similarity with the fauna in the uppermost sandy part of the Husbergøya Formation in Norway, included into the uppermost Rawtheyan Stage (Brenchley \& Cocks 1982; Owen et al. 1990).

The use of the term "Jonstorp" has been controversial. In the East Baltic the term is used for the up to $25 \mathrm{~m}$ thick early Pirgu deposits. In Sweden this formation, consisting of the Lower Jonstorp, Öglunda Limestone, and Upper Jonstorp (Jaanusson 1963), is up to $20 \mathrm{~m}$ thick and is correlated with the entire Pirgu Stage in the East Baltic, ranging there up to $90 \mathrm{~m}$ in thickness. The successions of lithologies in the central East Baltic and Sweden differ by the opposite positions of the red deposits (Jonstorp sensu stricto and Upper Jonstorp) in relation to pure limestones (Paroveja and Öglunda) in the sequence of the Pirgu Stage. The features indicating the middle Pirgu age (C. rugata Biozone) of the red-coloured deposits in the East Baltic are only found in the sections with a reduced stage thickness. In shallowing-upwards conditions during late Pirgu time the main area of red deposits shifted to the west, and the red-coloured Upper Jonstorp Formation was formed in Sweden. This supposition may explain the different interpretations of the age of the Jonstorp Formation in the East Baltic and Sweden, but it should be tested on more material and by using different methods, such as the carbon isotope studies, detailed conodont successions, and new data on the chemical composition of bentonites and their reliability for correlation.

\section{ACKNOWLEDGEMENTS}

The paper is a contribution to IGCP Project 503. We are grateful to D. Kaljo for support during the whole period of study and for critical notes and suggestions on the first draft of the manuscript. We are very thankful to both reviewers, Tõnu Meidla and Mark Harris for their critical remarks and assistance with the manuscript and figures. This research was supported by the Estonian Science Foundation (grants Nos. 5922 and 6127). 


\section{REFERENCES}

Ainsaar, L., Meidla, T. \& Tinn, O. 2004. Middle and Upper Ordovician stable isotope stratigraphy across the facies belts in the East Baltic. In WOGOGOB-2004, 8th Meeting of the Working Group on the Ordovician Geology of Baltoscandia, May 13-18, 2004, Tallinn and Tartu, Estonia. Conference Materials, Abstracts and Field Guidebook (Hints, O. \& Ainsaar, L., eds.), pp. 11-12. Tartu.

Bauert, G. \& Bauert, H. 1998. Distribution of chitinozoans in the Tartu (453) core. Appendix 14. In Tartu (453) Drill Core (Põldvere, A., ed.). Estonian Geol. Sections, 1.

Brangulis, A. P. (ed.). 1978. Resheniya mezhvedomstvennogo regional'nogo stratigraficheskogo soveshchaniya po razrabotke unifitsirovannykh stratigraficheskikh skhem Pribaltiki $1976 \mathrm{~g}$. s unifitsirovannymi stratigraficheskimi korrelyatsionnymi tablitsami. Leningrad (in Russian).

Brangulis, A. P., Gailite, L. K., Zabels, A. J., Springis, T. K., Ulst, R. Z., Fridrihsone, A. I. \& Yakovleva, V. I. 1989. Sratotipicheskie i opornye razrezy venda, kembriya i ordovika Latvii. Zinatne, Riga (in Russian).

Brenchley, P. J. \& Cocks, L. R. M. 1982. Ecological associations in a regressive sequence: the latest Ordovician of the Oslo-Asker District, Norway. Palaeontology, 25, 783-815.

Brenchley, P. J., Marshall, J. D., Hints, L. \& Nõlvak, J. 1997. New isotopic data solving an old biostratigraphic problem: the age of the upper Ordovician brachiopod Holorhynchus giganteus. J. Geol. Soc. London, 154, 335-342.

Brenchley, P. J., Carden, G. A., Hints, L., Kaljo, D., Marshall, J. D., Martma, T., Meidla, T. \& Nõlvak, J. 2003. High-resolution stable isotope stratigraphy of the Upper Ordovician sequence: constraints on the timing of bioevents and environmental changes associated with mass extinction and glaciation. GSA Bull., 115, 89-104.

Dahlqvist, P. 2004. Late Ordovician (Hirnantian) depositional pattern and sea-level change in shallow marine to shoreface cycles in central Sweden. Geol. Mag., 141, 605-616.

Floden, T., Puura, V., Söderberg, P., Tuuling, I. \& Suuroja, K. 1994. The Ordovician-Silurian transition beds in the seafloor between Gotland and Hiiumaa islands, Baltic Proper. Proc. Estonian Acad. Sci. Geol., 43, 1-17.

Friedman, G. M. 1965. Terminology of crystallization textures and fabrics in sedimentary rocks. J. Sedim. Petrol., 35, 643-655.

Gailite, L. K. 1979. Ordovician System. In Geologicheskoe stroenie i poleznye iskopaemye Latvii (Misans, J. P., Brangulis, A. P., Danilans, I. J. \& Kuršs, V. M., eds.), pp. 38-57. Zinatne, Riga.

Harris, T. M., Sheehan, P. M., Ainsaar, L., Hints, L., Männik, P., Nõlvak, J. \& Rubel, M. 2004. Upper Ordovician sequences of western Estonia. Palaeogeogr. Palaeoclimatol. Palaeoecol., 210, 135-148.

Hints, L. 1993. Holorhynchus (Pentamerida, Brachiopoda) in the Upper Ordovician of Estonia. Proc. Estonian Acad. Sci. Geol., 42, 118-123.

Hints, L. \& Meidla, T. 1997. Keila Stage. Oandu Stage. Rakvere Stage. Nabala Stage.Vormsi Stage. Pirgu Stage. Porkuni Stage. In Geology and Mineral Resources of Estonia (Raukas, A. \& Teedumäe, A., eds.), pp. 74-88. Estonian Academy Publishers, Tallinn.

Hints, L., Meidla, T., Nõlvak, J. \& Sarv, L. 1989. Some specific features of the Late Ordovician evolution in the Baltic Basin. Proc. Acad. Sci. Estonian SSR Geol., 38, 83-87.

Hints, L. Meidla, T., Gailite, L.-I. \& Sarv, L. (comp.). 1993. Catalogue of Ordovician Stratigraphical Units and Stratotypes of Estonia and Latvia. Baltic Stratigraphic Association, Institute of Geology, Estonian Academy of Sciences, Tallinn.

Hints, L., Meidla, T. \& Nõlvak, J. 1995. Ordovician sequences of the East European Platform. Geologija, 17, 58-63.

Hints, L., Oraspõld, A. \& Nõlvak, J. 2004. Pirgu Stage in the East Baltic: lithotypes, biozonation and problems of correlation. In WOGOGOB-2004, 8th Meeting of the Working Group on 
the Ordovician Geology of Baltoscandia, May 13-18, 2004, Tallinn and Tartu, Estonia. Conference Materials, Abstracts and Field Guidebook (Hints, O. \& Ainsaar, L., eds.), pp. 41-42. Tartu.

Hints, L., Nõlvak, J., Männik, P. \& Oraspõld, A. 2005. Proposal for the boundary stratotype of the Pirgu Regional Stage (Upper Ordovician) in the East Baltic. In The Sixth Baltic Stratigraphical Conference. Abstracts (Koren', T., Evdokimova, I. \& Tolmacheva, T., eds.), pp. 34-37. St. Petersburg.

Jaanusson, V. 1944. Übersicht der Stratigraphie der Lyckholm-Komplexstufe. Soc. Geol. Finl., 16, 92-100.

Jaanusson, V. 1956. Untersuchungen über den oberordovizischen Lyckholm-Stufenkomplex in Estland. Bull. Geol. Inst. Univ. Upsala, 36, 369-400.

Jaanusson, V. 1963. Classification of the Harjuan (Upper Ordovician) rocks of the mainland of Sweden. GFF, 85, 110-144.

Jaanusson, V. 1982a. Introduction to the Ordovician of Sweden. In Field Excursion Guide. IV International Symposium on the Ordovician System (Bruton, D. L. \& Williams, S. H., eds.). Pal. Contr. Univ. Oslo, 279, 1-9.

Jaanusson, V. 1982b. The Siljan District. In Field Excursion Guide. IV International Symposium on the Ordovician System (Bruton, D. L. \& Williams, S. H., eds.). Pal. Contr. Univ. Oslo, 279, $15-42$.

Jaanusson, V. 1995. Confacies differentiation and upper Middle Ordovician correlation in the Baltoscandian Basin. Proc. Estonian Acad. Sci. Geol., 44, 73-86.

Kala, E. A., Eltermann, G. J. et al. 1967. Otchet Pajdeskogo otryada o kompleksnoj geologo-gidrogeologicheskoj s"emke mashtaba 1:200000 tsentral'noj chasti ÉSSR (list=-35-VIII) za 1963-1966 godu. Unpublished report 2927, Geological Survey of Estonia (in Russian).

Kaljo, D. \& Hints, L. 1997. Late Ordovician-Early Silurian succession of paleoecosystems in Estonia. Paleontol. J., 30, 693-700.

Kaljo, D., Nestor, H. \& Põlma, L. 1988. East Baltic Region. - Global analysis of the Ordovician/ Silurian boundary. Brit. Mus. (Nat. Hist.) Bull. (Geol.), 43, 85-91.

Kaljo, D., Hints, L., Hints, O., Martma, T. \& Nõlvak, J. 1999. Carbon isotope excursions and coeval biotic-environmental changes in the late Caradoc and Ashgill of Estonia. In Quo vadis Ordovician? (Kraft, P. \& Fatka, O., eds.). Acta Univ. Carolinae Geol., 43, 507-510.

Kaljo, D., Hints, L., Martma, T. \& Nõlvak, J. 2001. Carbon isotope stratigraphy in the latest Ordovician of Estonia. Chem. Geol., 175, 49-59.

Kaljo, D., Hints, L., Martma, T., Nõlvak, J. \& Oraspõld, A. 2004. Late Ordovician carbon isotope trend in Estonia, its significance in stratigraphy and environmental analysis. Palaeogeogr. Palaeoclimatol. Palaeoecol., 210, 165-185.

Kiipli, E., Kallaste, T. \& Kiipli, T. 2004. Metabentonites of the Pirgu Stage (Ashgill, Upper Ordovician) of the East Baltic. In WOGOGOB-2004, 8th Meeting of the Working Group on the Ordovician Geology of Baltoscandia, May 13-18, 2004, Tallinn and Tartu, Estonia. Conference Materials, Abstracts and Field Guidebook (Hints, O. \& Ainsaar, L., eds.), pp. 51-52. Tartu.

Kirs, E. 1967. Ülemordoviitsiumi litostratigraafiast ja litoloogiast Koksvere ning Viljandi puurprofiilide põhjal. Bachelor thesis, University of Tartu (unpublished manuscript).

Kõrts, A., Einasto, R., Männil, R. \& Radionova, E. 1990. Calcareous algae. In Field Meeting Estonia 1990: An Excursion Guidebook (Kaljo, D. \& Nestor, H., eds.), pp. 97-100. Institute of Geology, Estonian Academy of Sciences, Tallinn.

Lapinskas, P. 1968. Lithostratigraphic complexes of the Upper Ordovician-Lower Silurian deposits in the western part of the southern Baltica. In Stratigraphy of the Baltic Lower Paleozoic and Its Correlation with Other Areas (Grigelis, A. A., ed.), pp. 155-169. Mintis, Vilnius.

Lapinskas, P. P. 1976. Stratigraphic subdivision and correlation of Upper Ordovician deposits of the southern East Baltic. In Materialy po stratigrafii Pribaltiki (Grigelis, A. A., ed.), pp. 42-44. Mintis, Vilnius. 
Laškov, E. \& Paškevičius, J. 1989. Stratigraphic hiati and breaks in sedimentation in the Ordovician section of the western margin of the East European Platform. Lietuvos aukštuju mokslo darbai, Geologija, 10, 12-36 (in Russian).

Laškov, E. \& Paškevičius, J. 1991. Paroveja Formation. In Stratigraficheskij slovar' SSSR. Novye stratigraficheskie podrazdeleniya paleozoya SSSR. Nedra, Leningrad.

Laškov, E., Paškevičius, J. \& Sidaravičiene, N. 1984. Lithostratigraphic subdivision of the Ordovician rocks of the Central Lithuanian depression. In Stratigrafiya drevnepaleozoiskikh otlozhenij Pribaltiki (Männil, R. M. \& Mens, K. A., eds.). pp. 77-93. Tallinn.

Laškovas, J. 2000. The Sedimentation Environments of the Ordovician Basin in the Southwestern Margin of the East European Platform and Lithogenesis of Deposits. Institute of Geology, Vilnius.

Laškovas, J., Paškevičius, J., Paškevičiene, L. \& Saladžius, V. 1993. Ordovician stratigraphic scheme. Lietuvos vendo-devonu stratotipu katalogas. Vilnius.

Lepisto, A. 1967. Ardu puursüdamiku ülemordoviitsiumi litostratigraafiline iseloomustus. Bachelor thesis, University of Tartu (unpublished manuscript).

Männik, P. 1992. Upper Ordovician and Lower Silurian Conodonts in Estonia. Abstract. Doctoral thesis at the University of Tartu. Tartu.

Männik, P. 2001. Distribution of conodonts. In Valga (10) Drill Core (Põldvere, A., ed.). Estonian Geol. Sections, 3, 10-12.

Männik, P. 2003. Distribution of conodonts. In Ruhnu (500) Drill Core (Põldvere, A., ed.). Estonian Geol. Sections, 5, 17-23.

Männil, R. M. 1966. Evolution of the Baltic Basin During the Ordovician. Valgus, Tallinn (in Russian).

Männil, R. M. 1987. Explanatory text to the stratigraphic chart of Ordovician deposits. In Resheniya mezhvedomstvennogo stratigraficheskogo soveshchaniya po ordoviku i siluru VostochnoÉvropejskoj platformy 1984 g. s regional'nymi stratigraficheskimi skhemami (Kaljo, D. L., ed.), pp. 17-46. VSEGEI, Leningrad.

Männil, R. 1990. The Ordovician of Estonia. In Field Meeting Estonia 1990: An Excursion Guidebook (Kaljo, D. \& Nestor, H., eds.), pp. 11-20. Institute of Geology, Estonian Academy of Sciences, Tallinn.

Männil, R. \& Meidla, T. 1994. The Ordovician System of the East European Platform (Estonia, Latvia, Lithuania, Byelorussia, parts of Russia, the Ukraine and Moldova). In The Ordovician System of the East European Platform and Tuva (Southeastern Russia) (Webby, B. D., Ross, R. J. \& Zhen, Y. Y., eds.). IUGS Publ., 28, A, 1-52.

Männil, R. \& Rõõmusoks, A. 1984. A revision of the lithostratigraphic subdivision of the Ordovician of North Estonia. In Stratigrafiya drevnepaleozoiskikh otlozhenij Pribaltiki (Männil, R. \& Mens, K., eds.), pp. 52-62. Institute of Geology, Tallinn (in Russian).

Männil, R., Põlma, L. \& Hints, L. 1968. Stratigraphy of the Viru and Harju Series (Ordovician) of the central East Baltic area. In Stratigraphy of the Baltic Lower Paleozoic and Its Correlation with Other Areas (Grigelis, A. A., ed.), pp. 81-110. Mintis, Vilnius.

Meidla, T. 1983. Die ostracoden aus den grenzschichten der Vormsi- und Pirgu-Stufen Westestlands. Eesti ENSV Tead. Akad. Toim. Geol., 32, 53-59.

Meidla, T. 1996. Late Ordovician Ostracodes of Estonia. Fossilia Baltica, 2. Tartu.

Meidla, T. 2001. Distribution of ostracods. In Valga (10) Drill Core (Põldvere, A., ed.). Estonian Geol. Sections, 3, 10-12.

Meidla, T., Hints, L., Männik, P. \& Nõlvak, J. 1990. Locality 2:4 Ristna cliff. In Field Meeting Estonia 1990. An Excursion Guidebook (Kaljo, D. \& Nestor, H., eds.), pp. 134-136. Institute of Geology, Estonian Academy of Sciences, Tallinn.

Modliński, Z. \& Szymański, B. 1997. The Ordovician lithostratigraphy of the Peribaltic Depression (NE Poland). Geol. Quarterly, 41, 273-288.

Nestor, H. \& Einasto, R. 1997. Ordovician and Silurian carbonate sedimentation basin. In Geology and Mineral Resources of Estonia (Raukas, A. \& Teedumäe, A., eds.), pp. 192-204. Estonian Academy Publishers, Tallinn. 
Nielsen, A. T. 2004. Ordovician sea level changes: a Baltoscandian perspective. In The Great Ordovician Biodiversification Event (Webby, B. D., Paris, F., Droser, M. L. \& Percival, I. G., eds.), pp. 84-93. Columbia University Press, New York.

Nõlvak, J. 1980. Chitinozoans in biostratigraphy of the northern east Baltic Ashgillian. A preliminary report. Acta Palaeontol. Polonica, 25, 253-260.

Nõlvak, J. 1984. Rasprostranenie kislotoustoichivykh mikrofossilii v razrezakh ashgilla Severnoj Éstonii. VINITI N. 8209-84, Moscow (in Russian).

Nõlvak, J. 1986. Rasprostranenie khitinozoij v razrezakh verkhnego ordovika Éstonii. VINITI N. 8526-B86, Moscow (in Russian).

Nõlvak, J. 1988. Khitinozoj verkhnego ordovika Sredne-Litovskogo progiba. VINITI N. 7811-B88, Moscow (in Russian).

Nõlvak, J. 1997. Ordovician. Introduction. In Geology and Mineral Resources of Estonia (Raukas, A. \& Teedumäe, A., eds.), pp. 52, 54-55. Estonian Academy Publishers, Tallinn.

Nõlvak, J. 1999. Ordovician chitinozoan biozonation of Baltoscandia. In Quo vadis Ordovician? (Kraft, P. \& Fatka, O., eds.). Acta Univ. Carolinae Geol., 43, 287-290.

Nõlvak, J. 2001. Distribution of chitinozoans. In Valga (10) Drill Core (Põldvere, A. ed.). Estonian Geol. Sections, 3, 8-10.

Nõlvak, J. 2002. Chitinozoan Biostratigraphy in the Ordovician of Baltoscandia. Thesis on Natural and Exact Sciences B14. TTU Press, Tallinn.

Nõlvak, J. 2003. Distribution of Ordovician chitinozoans. In Ruhnu (500) Drill Core (Põldvere, A., ed.). Estonian Geol. Sections, 5, 23-25.

Nõlvak, J. \& Grahn, Y. 1993. Ordovician chitinozoan zones from Baltoscandia. Rev. Palaeobot. Palynol., 79, 245-269.

Nõlvak, J., Meidla, T. \& Hints, L. 1989. The Taučionys Formation (Holorhynchus Beds) in the Iljinskoje boring (Pskov District). Proc. Acad. Sci. Estonian SSR Geol., 38, 88-93.

Oraspõld, A. 1975. Lithological characterization of the Pirgu Stage in South Estonia. Acta Comment. Univ. Tartuensis, 359, 14-31 (in Russian).

Oraspõld, A. 1982. Lithological characterization of the boundary beds of the Vormsi and Pirgu stages in central Estonia. Acta Comment. Univ. Tartuensis, 527, 91-99 (in Russian).

Oraspõld, A. 1991. Microlithology of the boundary beds between the Vormsi and Pirgu stages (Upper Ordovician) in Paluküla stone pit in Island Hiiumaa. Acta Comment. Univ. Tartuensis, 934, 13-21 (in Russian).

Oraspõld, A. 1992. Detriidi hulk ja koostis Pirgu lademe $\left(\mathrm{O}_{3}\right)$ Tootsi, Halliku ja Oostriku kihistute karbonaatkivimites Kesk-Eesti idaosas (Torma puursüdamiku põhjal). Acta Comment. Univ. Tartuensis, 956, 86-94.

Oraspõld, A. \& Kala, E. 1982. Lithology of the Vormsi Stage in Estonia. Acta Comment. Univ. Tartuensis, 527, 51-74 (in Russian).

Oraspõld, A. \& Põldvere, A. 1992. Pirgu lade Kesk-Eesti idaosas. Acta Comment. Univ. Tartuensis, 956, 69-85.

Owen, A. W., Bruton, D. L., Bockelie, J. F. \& Bockelie, T. G. 1990. The Ordovician successions of the Oslo Region, Norway. Norges Geol. Unders. Spec. Publ. 4.

Paris, F., Achab, A., Asselin, E., Chen Xiao-hong, Grahn, Y., Nõlvak, J., Obut, O., Samuelsson, J., Sennikov, N., Vecoli, M., Verniers, J., Wang Xia-feng \& Winchester-Seeto, T. 2004. Chitinozoans. In The Great Ordovician Biodiversification Event (Webby, B. D., Paris, F., Droser, M. L. \& Percival, I. G., eds.), pp. 294-311. Columbia University Press, New York.

Paškevičius, J. 1968. Biostratigraphy and correlation of the Silurian terrigenous and carbonaceous formations of the southern Baltic. In Stratigraphy of the Baltic Lower Paleozoic and its Correlation with Other Areas (Grigelis, A., ed.), pp. 250-272. Mintis, Vilnius.

Paškevičius, J. 1994. Baltijos respubliku geologija. Vilnius.

Paškevičius, J. 1997. The Geology of the Baltic Republics. Geological Survey of Lithuania, Vilnius University, Vilnius. 
Perens, H. 1995. Ülemordoviitsiumist Põltsamaa-Jõgeva-Ruskavere joonel. In Liivimaa geoloogia (Meidla, T., Jõeleht, A., Kalm, V. \& Kirs, J., eds.), pp. 45-50. Tartu.

Põldvere, A. \& Kleesment, A. 1998. Basic concepts and terminology. In Tartu (453) Drill Core (Põldvere, A., ed.). Estonian Geol. Sections, 1, 7-10.

Põlma, L. 1972a. Skeletal debris content and composition in the sediments of the East Baltic Ordovician facial axial belt (Engure boring). Eesti NSV Tead. Akad. Toim. Keemia Geol., 21, 148-154 (in Russian).

Põlma, L. 1972b. Skeletal debris content and composition in the sediments of the northern facial belt of the East Baltic Ordovician (Rapla boring). Eesti NSV Tead. Akad. Toim. Keemia Geol., 21, 326-332 (in Russian).

Põlma, L. 1982. Comparative Lithology of the Ordovician Carbonate Rocks in the Northern and Middle East Baltic. Valgus, Tallinn (in Russian).

Ropot, V. F. \& Pushkin, V. I. 1987. Ordovician of Byelorussia. Nauka i Tekhnika, Minsk (in Russian).

Rõõmusoks, A. 1960. Ordovician System. In Geologiya SSR, XXVIII. Éstonskaya SSR (Orviku, K. K., ed.), pp. 55-112. Gostoptekhizdat, Moscow (in Russian).

Rõõmusoks, A. 1962. On the stratigraphy of the Harjuan Series of Estonia. ENSV Tead. Akad. Geol. Inst. Uurimused, X, 77-85 (in Russian).

Rõõmusoks, A. 1967a. Stratigrafiya viruskoj i har'yuskoj serij (ordovik) Severnoj Éstonii. Abstract of Doctoral thesis. Moscow-Tartu (in Russian).

Rõõmusoks, A. 1967b. Stratigrafiya viruskoj i har'yuskoj serij (ordovik) Severnoj Éstonii. A dissertation for the Doctor's degree in geological and mineralogical sciences. Manuscript. Moscow-Tartu (in Russian).

Rõõmusoks, A. 1983. Eesti aluspõhja geoloogia. Valgus, Tallinn.

Rõõmusoks, A. 2004. Ordovician strophomenoid brachiopods of northern Estonia. Fossilia Baltica, 3. Tartu.

Schmidt, F. 1858. Untersuchungen über die silurische Formation von Estland, Nord-Livland und Oesel. Arch. Naturk. Liv-, Est- und Kurl., Ser. I, Bd. 2, Dorpat.

Schmidt, F. 1881. Revision der ostbaltischen silurischen Trilobiten nebstgeognostischer Übersicht des ostbaltischen Silurgebiets. Abt. I: Phacopiden, Cheiruriden und Encrinuriden. Mém. Acad. Sci. St. Pétersb., sér. VII, XXX, 1.

Sidaravičiene, N. 1992. Ostrakody ordovika Litvy. Vilnius (in Russian).

Sidaravičiene, N. 1996. Lietuvos ordoviko ostrakodai, biostratigrafija. Vilnius.

Sidaravičiene, N. 1999. Lithuanian Stratigraphic Units. Geological Survey of Lithuania, Vilnius.

Smelror, M., Cocks, L. R. M., Mørk, A., Neuman, B. E. E. \& Nakrem, H. A. 1997. Upper OrdovicianLower Silurian strata and biota from offshore South Norway. Norsk Geol. Tidsskr., 77, $251-$ 268.

Stinkulis, G. 2003. Latvijas nogulumiež segas strātigrafiskā shēma. Latvijas Geol. vēstis, 11, 14-17.

Tuuling, I. \& Floden, T. 2001. The structure and relief of the bedrock sequence in the GotlandHiiumaa area, northern Baltic Sea. GFF, 123, 35-49.

Ulst, R. 1972. A local subdivision of Upper Ordovician of the middle Baltic Region. In Regional'naya geologiya Pribaltiki i Belorussii, pp. 7-20. Zinatne, Riga (in Russian).

Ulst, R. Z. 1992. Ordovician and Silurian of deep drill core sections on the Baltic Sea Shelf. In Paleontologiya i stratigrafiya fanerozoya Latvii i Baltijskogo morya (Ulst, R. Z., ed.), pp. 120-138. Zinatne, Riga (in Russian).

Ulst, R. Z. \& Gailite, L. K. 1970. Ordovician-Silurian boundary in Latvia and lithostratigraphical subdivisions of boundary deposits. In Paleontologiya i stratigrafiya Pribaltiki i Belorussii (Grigelis, A. A., ed.), pp. 283-295. Mintis, Vilnius.

Ulst, R. Z. \& Gailite, L. K. 1976. Ordovician System. In Stratigraficheskie skhemy Latvijskoj SSR (Birkis, A. P. et al., eds.), pp. 36-63. Zinatne, Riga (in Russian).

Ulst, R. Z., Gailite, L. K. \& Yakovleva, V. I. 1982. Ordovik Latvii. Zinatne, Riga (in Russian). 
Ulst, R. Z., Gailite, L. K. \& Springis, T. K. 1984. Lithostratigraphic subdivision of the subsurface Ordovician rocks of the Jelgava depression. In Stratigrafiya drevnepaleozoiskikh otlozhenij Pribaltiki (Männil, R. M. \& Mens, K. A., eds.), pp. 63-75. Institute of Geology, Tallinn (in Russian).

Vingisaar, P. 1977. Lithostratigraphy of the Vormsi and Pirgu stages (Upper Ordovician) of Estonia. In Voprosy regional'noj geologii (Ogneva, V. N., ed.), 2, 91-102.

Webby, B. D., Cooper, R. A., Bergström, S. M. \& Paris, F. 2004. Stratigraphic framework and time slices. In The Great Ordovician Biodiversification Event (Webby, B. D., Paris, F., Droser, M. L. \& Percival, I. G., eds.), pp. 41-47. Columbia University Press, New York.

\title{
Pirgu regionaalne lade (Ülem-Ordoviitsium) Baltikumis: litostratigraafia, biotsonaalsus ja korrelatsioon
}

\author{
Linda Hints, Asta Oraspõld ja Jaak Nõlvak
}

Ordoviitsiumi ladestu suurima (ligi $100 \mathrm{~m}$ ) paksusega Pirgu lade on Baltikumis esindatud üle 20 erineva litostratigraafilise üksusega (kihistu ja kihistikuga), mille korrelatsioon ja fatsiaalsed üleminekud on leidnud erinevat käsitlust. Artiklis on kirjeldatud Pirgu lademe koosseisu kuuluvaid kihistuid, ühendades fatsiaalselt sarnased üksused nelja gruppi: madalmerelised vähese savikusega lubjakivid ning savikad lubjakivid ja sügavamaveelised merglid ning puhtad lubjakivid. On analüüsitud Pirgu-ealiste setendite fatsiaalseid muutusi piki põhjalõunasuunalisi profiile, mis läbivad eri fatsiaalseid vööndeid. On iseloomustatud Pirgu lademe alumist piiri ja selle määramise lito- ning biostratigraafilisi kriteeriume. On esitatud Pirgu lademe kitiinikute biotsonaalne skaala ja üksuste korrelatsiooniskeem. On selgitatud termini "Jonstorp" kasutamist eri autorite poolt. Baltikumis kasutatakse nimetatud terminit Pirgu lademe alumise osa punavärviliste kivimite, Rootsis aga kogu sellele lademele vastavate hallide, kirjute ja punavärviliste kivimite kohta. Oletatakse, et Pirgu lademe punavärviliste kivimite moodustumine algas Baltikumis varem kui Skandinaavias, nii nagu see on teada Alam-Ordoviitsiumi kohta. Basseini eri piirkondi iseloomustavate geoloogiliste läbilõigete põhjal on esile toodud setendite maksimaalse kuhjumise piirkonnad Saaremaad ja Kesk-Eestit haaravas üleminekuvööndis ning Balti Basseini keskossa jääval Liivi Keele alal. Jälgitav on Pirgu lademe paksuse vähenemine lääne suunas ja punavärviliste setendite Kesk-Baltikumist pikemaajalisem kuhjumine piiratud aladel läänes (Läti loodeosas ja Eesti edelaosas). 